\title{
Espécies de Parmotrema (Parmeliaceae, Ascomycota) do litoral centro-sul do Estado de São Paulo II. Grupos químicos norstíctico e salazínico
}

\author{
Marcelo Pinto Marcelli ${ }^{1}$ e Michel Navarro Benatti ${ }^{1,2}$
}

Recebido em 14/10/2008. Aceito em 7/07/2009

RESUMO - (Espécies de Parmotrema sensu stricto (Parmeliaceae, Ascomycota) do litoral centro-sul do Estado de São Paulo II. Grupos químicos norstíctico e salazínico.). O levantamento das espécies pertencentes aos gêneros de grandes parmélias do litoral centro-sul do Estado de São Paulo revelou a ocorrência de nove espécies de Parmotrema sensu stricto (talos foliosos de lobos arredondados em geral com mais de $0,5 \mathrm{~cm}$ larg. com margens inferiores não rizinadas) contendo como constituintes químicos medulares os ácidos norstíctico ou salazínico. São tipicamente reconhecidos pela cor amarela que se torna avermelhada resultante dos testes de coloração com hidróxido de potássio. São apresentados uma chave de identificação, descrições, comentários e ilustrações, baseados em material brasileiro.

Palavras-chave: costões rochosos, liquens, manguezal, restinga, Parmotrema

ABSTRACT - (Species of Parmotrema sensu strict (Parmeliaceae, Ascomycota) of the south-central- coast of São Paulo state II. Chemical groups norstictic and salazinic). In a survey of the species pertaining to genera of large parmeliae occurring in the coastal areas of south-central São Paulo state, Brazil, nine species of Parmotrema sensu stricto (foliose thalli with rounded lobes usually more than $0,5 \mathrm{~mm}$ wide with nude lower margins) containing norstictic or salazinic acids as main medullar substances were found. These are typically recognized by the yellow then red staining potassium hydroxide spot tests. Identification key, descriptions, comments, and illustrations based on Brazilian material are provided for these species.

Key words: rocky shores, lichens, mangrove, restinga, Parmotrema

\section{Introdução}

O gênero Parmotrema A. Massal. é caracterizado pelos lobos de ápices largos e arredondados (com mais de $0,5 \mathrm{~cm}$, muitas vezes ultrapassando 2 ou $3 \mathrm{~cm}$ de largura), ausência de pseudocifelas (poros com extravasamento de hifas medulares), ocorrência freqüente de cílios marginais, ampla zona marginal do córtex inferior nua, rizinas geralmente simples, e ascósporos elipsóides de paredes espessas (Brodo et al. 2001; Nash \& Elix 2002). Mais de trezentas espécies são conhecidas em todo o mundo (Nash \& Elix 2002), das quais aproximadamente um terço é citado para o Brasil (Marcelli 2004).

Todas as espécies mencionadas neste trabalho possuem como característica comum apresentarem ácidos norstíctico ou salazínico medulares, ambos reconhecidos por apresentarem testes de coloração com reações $\mathrm{K}+$ amarelo $\rightarrow$ vermelho claro ou escuro e P+ amarelo ou alaranjado. Em cromatografia de camada delgada (CCD) estas substâncias se apresentam com valores de referência (Rfs), rastros e colorações bem diferentes.

A área abrangida por esta pesquisa e os respectivos dados climáticos são descritos em Benatti \& Marcelli (2009). Ela está localizada no litoral centro-sul do Estado de São Paulo, entre os municípios de Bertioga e Cananéia. Este trabalho objetivou realizar o levantamento das espécies de Parmotrema sensu stricto com ácidos norstíctico e salazínico medulares que ocorrem nos diversos ambientes (manguezais, restingas, costões rochosos e zonas urbanizadas) do litoral centro-sul paulista, até então inexistente.

São fornecidos uma chave artificial de identificação, descrições comentadas, dados das localidades e de ambientes para as espécies encontradas.

\section{Material e métodos}

Os ambientes estudados incluem (1) os costões rochosos, quase sempre despidos de vegetação e expostos à forte insolação, à salinidade da maré e à ação altamente energética das ondas, (2) a vegetação de restinga, constituída pelas matas de jundu e as florestas de restinga, que compõem grande parte da vegetação da planície costeira atrás da faixa das dunas, instaladas sobre as extensas faixas arenosas na orla marítima, e (3) os manguezais, formações caracterizadas pelas florestas que se erguem sobre um substrato plano, lodoso, localizadas nas bordas de estuários e foz de rios, sendo freqüentemente inundados pelas marés (Andrade \& Lamberti 1965; Andrade 1967; Eiten 1970).

A metodologia de coleta é descrita em Benatti \& Marcelli (2007). O material foi identificado conforme Fink (1905), Galloway (1985) e Hale (1979). Foram realizadas excursões pontuais de coleta a várias localidades urbanas e naturais de todos os municípios da região. $\mathrm{O}$ material foi depositado no Herbário Maria Eneyda P. Kauffmann Fidalgo (SP), do Instituto de Botânica, em São Paulo.

Para as análises morfológicas foram observadas características macro e microscópicas dos espécimes, mediante uso de estereomicroscópio e microscópio óptico. Foram analisadas características de estruturas somáticas e de reprodução, tanto direta como indireta, dos talos (Benatti 2005). A metodologia de análises químicas (testes de coloração, irradiação por luz UV e CCD com solvente C) seguiu Asahina \& Shibata (1954), Walker \& James (1980), White \& James (1985), Huneck \& Yoshimura (1996), Bungartz (2001) e Orange et al. (2001), com pequenas mudanças ou adaptações.

Devido a aparentes discordâncias encontradas em literatura, estabelecemos que a largura dos lobos medidos neste trabalho bem como nos outros referentes a mesma localidade de estudo refere-se a largura máxima dos lobos distais (na porção central), e não a da base tal como é mostrado em Hale (1979).

Embora sejam discutidos os aspectos mais relevantes pertinentes a cada uma das espécies encontradas, outras comparações e detalhes podem ser encontrados em Benatti (2005).

\section{Resultados e discussão}

No litoral centro-sul do Estado de São Paulo foram encontradas oito espécies de Parmotrema contendo ácido

Instituto de Botânica, Seção de Micologia e Liquenologia, São Paulo, SP, Brasil

2 Autor para correspondência: michel_benatti@yahoo.com.br 
154 Marcelli \& Benatti: Espécies de Parmotrema (Parmeliaceae, Ascomycota) do litoral centro-sul do Estado de São Paulo II...

salazínico medular e apenas uma contendo ácido norstíctico. Três delas foram recentemente descritas (Benatti et al. 2008) e uma é citação recente para o estado de São Paulo. As outras cinco espécies já foram mencionadas para São Paulo, embora exista apenas um único trabalho brasileiro contendo chaves e descrições para espécies deste grupo (Eliasaro \& Donha 2003).

Para todas as espécies descritas aqui, os testes de coloração do córtex superior são $\mathrm{K}+$ amarelo (atranorina) as da medula $\mathrm{K}+$ amarelo $\rightarrow$ vermelho claro/vermelho alaranjado, C-, e P+ amarelo (ácido norstíctico e conorstíctico) ou $\mathrm{K}+$ amarelo $\rightarrow$ vermelho escuro, e $\mathrm{P}+$ alaranjado (ácidos salazínico e consalazínico). Nenhum dos ácidos medulares reage ao teste $\mathrm{C}$ e o teste $\mathrm{KC}$ resulta numa forma diluída do teste K. A exceção para testes corticais é P. flavescens, cujo córtex superior reage $\mathrm{K}-, \mathrm{KC}+$ amarelo, (presença de ácido úsnico com traços de atranorina), cuja medula também contém o ácido girofórico, mas que foi detectado somente em cromatografia (CCD). Parmotrema asperum também contém ácido divaricático medular, que só foi detectado em cromatografia (CCD/CLAP). Tanto Parmotrema spinibarbe como P. ultralucens contêm também liquexantona medular, que emite um brilho amarelo-dourado característico quando submetida à luz UV de ondas longas.

Cinco espécies apresentam propagação direta por formação de sorédios [Parmotrema rubifaciens (Hale) Hale, com ácido norstíctico, e P.anchietanum Marcelli, Benatti \& Elix, P. asperum Benatti, Marcelli \& Elix, P. cristiferum (Taylor) Hale e $P$. spinibarbe (Kurokawa) Hale ex DePriest \& B. Hale, com ácido salazínico], duas por formação de isídios [P. flavescens (Krempelhuber) Hale e P. ultralucens (Krog) Hale], e outras duas somente por formação de apotécios ( $P$. expansum Hale e $P$. hypermaculatum Marcelli, Benatti \& Elix). Parmotrema cristiferum e P. rubifaciens são corticícolas, enquanto $P$. anchietanum, $P$. asperum, $P$. expansum, P. flavescens, $P$. hypermaculatum e $P$. spinibarbe são saxícolas. Somente $P$. ultralucens foi encontrada tanto em substratos arbóreos como rochosos.

À exceção apenas dos espécimes de $P$. expansum e $P$. hypermaculatum, não foram encontrados apotécios nos materiais vistos, e picnídios ou conídios não foram observados somente em espécimes de $P$. cristiferum e P. rubifaciens.

Chave artificial de identificação para as espécies de Parmotrema sensu stricto contendo ácidos norstíctico ou salazínico (não inclui o grupo de espécies anteriormente em Rimelia Hale \& Fletcher)

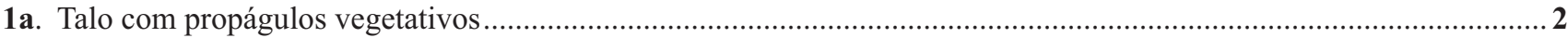

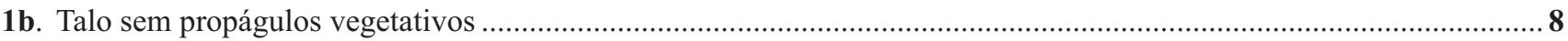

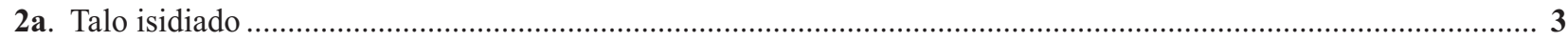

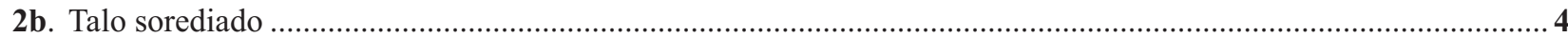

3a. Córtex superior verde amarelado, com ácido úsnico ( $\mathrm{K}-$ ), emaculado, margens pouco ciliadas, cílios simples, isídios simples eciliados, medula UV- sem liquexantona; só saxícola.

P. flavescens

3b. Córtex superior cinza esverdeado, com atranorina ( $\mathrm{K}+$ amarelo), maculado, margens bastante ciliadas, cílios simples a cespitosos, isídios simples a coralóides parcialmente ciliados, medula UV+ com liquexantona; saxícola ou corticícola

P. ultralucens

4a. Lobos largos e arredondados, freqüentemente com mais de $1 \mathrm{~cm}$ larg., com sorais marginais principalmente lineares ou sobre dobras do talo......

4b. Lobos estreitos, subarredondados a subtruncados, poucas vezes ultrapassando $0,5 \mathrm{~cm}$ larg., com pústulas que se desmancham em sorais, laminais ou subapicais, subcapitados a irregulares

5a. Talo com margens ciliadas, com cílios simples a ramificados cespitosos; medula com liquexantona (UV+ amarelo-dourado).

5b. Talos com margens eciliadas (ou com alguns cílios simples e escassos, mais comuns em parte velhas); medula sem liquexantona (UV-)

6a. Lobos em geral 1-2 cm larg., talo subcoriáceo, sorais lineares, medula $\mathrm{K}+$ amarelo $\rightarrow$ vermelho escuro (ácido salazínico), sem pigmentos alaranjados $\mathrm{K}+$

P. cristiferum

6b. Lobos em geral 0,5-1 cm larg., talo submembranáceo, sorais aglutinados e coalescentes, medula $\mathrm{K}+$ amarelo $\rightarrow$ vermelho claro (ácido norstíctico), com manchas esparsas de pigmento alaranjado $\mathrm{K}+$ vermelho escuro

7a. Talo sublaciniado a laciniado e muito lacinulado, lobos em geral 1-3 mm larg. com cílios freqüentes, máculas mais restritas às partes distais, sorais efêmeros freqüentemente desagregando e expondo o córtex inferior

P. anchietanum

7b. Talo sublobado pouco sublacinulado, lobos em geral 3-6 mm larg. com cílios esparsos, máculas distintas visíveis por todo o córtex, sorais agregados freqüentemente tornando-se corticados, nunca expondo o córtex inferior. 
8a. Talo resistente, com máculas espessas mesmo nas partes jovens, cílios em geral simples, ascósporos 10-14 ×6,5-9 $\mu \mathrm{m}$, conídios cilíndricos filiformes 7-14 × $1 \mu \mathrm{m}$

P. hypermaculatum

8b. Talo um pouco quebradiço, com máculas finas, cílios com freqüência ramificados, ascósporos $16-18 \times 9 \mu \mathrm{m}$, conídios cilíndricos baciliformes $6-7 \times 0,5 \mu \mathrm{m}$

P. expansum

1. Parmotrema anchietanum Marcelli, Benatti \& Elix, Mycotaxon 103: 42. 2008.

Fig. 1a-b

Talo sublaciniado a quase laciniado, acinzentado claro, até $16,0 \mathrm{~cm}$ diâm., coriáceo, saxícola. Lobos de ramificação irregular às vezes subdicotômica, 1,0-3,0 $(-5,5) \mathrm{mm}$, imbricados nas partes jovens logo se tornando amontoados, de adnatos a pouco elevados, pouco adpressos, os ápices subtruncados a truncados, de quase planos a subcôncavos, as margens crenadas a irregularmente dissecadas, pouco ascendentes, subonduladas, lacinuladas. Superfície contínua a irregularmente quebrada, lisa a parcialmente rugosa. Lacínulas do tipo adventícias, regulares e abundantes nas margens e ápices dos lobos, curtas e planas, 0,2-3,2 x 0,2-1,0 mm, em geral simples a mais raramente furcadas ou irregulares, de truncadas a agudas, freqüentemente misturadas a pequenos lóbulos jovens irregulares, lado de baixo concolorido à margem inferior. Máculas distintas nas partes jovens, porém fracas no centro, de puntiformes a lineares laminais ou reticulares subapicais, às vezes originando quebras. Cílios negros, simples, $0,2-1,6 \mathrm{x}$ ca. $0,05 \mathrm{~mm}$, freqüentes por toda a margem. Sorais capitados ou irregulares às vezes coalescentes, originados de pústulas efêmeras, com freqüência expondo o córtex inferior (ver adiante). Sorédios de subgranulares a granulares, às vezes grosseiros. Pústulas efêmeras, comumente decompondo-se em sorédios, de submarginais a subapicais nos lobos ou subapicais das lacínulas não alcançando as extremidades, freqüentes também sobre as dobras da lâmina, capitadas a irregulares. Isídios ausentes. Medula branca, sem pigmentações, às vezes manchada pela hidrólise e oxidação do ácido salazínico. Lado de baixo negro, lustroso, liso, pouco papilado. Margem inferior marrom, lustrosa, 1,0-3,0 $\mathrm{mm}$ larg., nua a parcialmente rizinada, atenuada, lisa, pouco papilada. Rizinas negras mesmo na margem, de simples a furcadas ou às vezes irregulares, freqüentemente aglutinadas, $0,20-1,40(-3,60) \times 0,05-0,10 \mathrm{~mm}$, de freqüentes a abundantes em algumas partes, homogêneas. Apotécios não encontrados. Picnídios submarginais comuns, às vezes também nas lacínulas, de ostíolo negro. Conídios filiformes curtos, $6,5-11,0 \times 1,0 \mu \mathrm{m}$.

Material estudado: BRASIL. São Paulo: Ubatuba, Ilha Anchieta, costão rochoso do Saco Grande, 23/XI/2003, A.A.Spielmann et al. 557a, $557 b$ (holótipo, SP); idem, costão rochoso em local sombreado, 23/XI/2003, L.S.Canêz \& A.A.Spielmann $607 b$ (SP); idem, costão rochoso, 23/ XI/2003, L.S.Canêz \& A.A.Spielmann 620 (SP).
Distribuição conhecida: América do Sul. Brasil: SP (Benatti 2005; Benatti et al. 2008).

Comentários: Parmotrema anchietanum é caracterizada pelos lobos sublaciniados à quase laciniados e muito lacinulados, pela cor cinza clara, pelas margens ciliadas e pelos sorais de origem pustular que surgem principalmente nas áreas subapicais ou submarginais dos lobos e das lacínulas.

Embora possa ser percebida a presença de máculas principalmente nos lobos mais jovens, talos de $P$. anchietanum não possuem um córtex superior tão maculado quanto os que são comuns às espécies dos antigos gêneros Canomaculina (máculas efiguradas) ou Rimelia (máculas reticuladas). As máculas são às vezes difíceis de serem notadas, e às vezes quase imperceptíveis por causa da cor acinzentada do talo.

Embora esta espécie tenha sido descrita como formando máculas que se restringiam na maioria às partes mais distais dos lobos (Benatti 2005; Benatti et al. 2008) e de aspecto mais linear, estudando os padrões de máculas das espécies de Parmotrema com ácido salazínico medular, Spielmann (com. pess.) visualizou de fato a formação de máculas reticulares em talos de $P$. anchietanum, ainda que mais restritas às áreas citadas.

As margens inferiores nos espécimes de $P$. anchietanum são apenas parcialmente nuas, sendo que em alguns lobos surgem rizinas próximas da borda, enquanto que em outros crescem por toda a área da margem. É comum em espécies de Parmotrema que lobos com margens e/ou ápices sorediados possuam uma margem de cor diferenciada (e.g., branca ou creme), o que não ocorre nesta espécie.

Os sorais se dispõem quase que na totalidade submarginais ou subapicais próximos aos ápices das lacínulas a uma curta distância das extremidades, e em menor quantidade nos lobos ou sobre as dobras dos talos. Os sorédios originam-se de pústulas efêmeras de aspecto espumoso, que se decompõem e caducam, com tendência a expor o córtex inferior.

Parmotrema asperum Benatti, Marcelli \& Elix é sublobada, tem lobos mais largos $(2,0-6,5 \mathrm{~mm})$, margens e lacínulas mais irregulares, é menos ciliada, e os sorais aglutinam-se pela dissolução incompleta das pústulas ao invés de desagregarem ao ponto de deixar à mostra o córtex inferior, avançando até as extremidades, fazendo com que as bordas por vezes involuam. As máculas em $P$. asperum são muito mais evidentes que em $P$. anchietanum, tornandose reticulares e densas e deixando pequenas "manchas" reduzidas de áreas com algas, dando ao talo uma coloração acinzentada "leitosa". 
Parmotrema cristiferum (Taylor) Hale é corticícola, tem lobos mais arredondados e bem mais largos (comumente $1,0-2,0 \mathrm{~cm})$ e talo com coloração cinza esverdeada. Os sorais são marginais lineares e sinuosos e não pustulares, e os sorédios tendem a uma granulação mais fina. As margens apresentam ocasionalmente cílios, mais comuns nas partes mais velhas do centro do talo (Benatti 2005).

Parmotrema stuppeum (Taylor) Hale é corticícola, possui lobos mais arredondados e largos $(1,0-1,5 \mathrm{~cm})$ e sorais lineares marginais como os de P.cristiferum, com cílios mais longos (2,0-3,0 mm), que são mais raros em espécimes muito sorediados, além de conídios menores (4,0-6,0 $\mu \mathrm{m}$ ) do que os encontrados em P. anchietanum (Hale 1965; Brodo et al. 2001).

Parmotrema margaritatum (Hue) Hale difere pela forma dos lobos, similares aos de P. cristiferum e P. stuppeum (Hale 1965), que apesar do diâmetro menor são mais largos que os de $P$. anchietanum $(7,0-10,0 \mathrm{~mm}$ larg.). Os sorais diferem por serem capitados nos ápices de pequenas lacínulas marginais e por recobrirem-nas, fazendo com que os lobos fiquem revolutos (Hale 1965; Brodo et al. 2001).

Parmotrema reticulatum (Taylor) Hale difere por ser corticícola, sublobada (não sublaciniada e lacinulada como ocorre com $P$. anchietanum), ter o córtex superior rimoso e com máculas reticulares, sorais submarginais lineares interrompidos nos lobos ou parcialmente apicais em lacínulas muito curtas, e margens inferiores rizinadas até quase as bordas com rizinas simples a esquarrosas (Benatti 2005).

Parmotrema subsumptum (Nylander) Hale tem lobos mais largos $(0,5-1,5 \mathrm{~cm})$ e arredondados que os de $P$. anchietanum. Seus sorais iniciam-se como marginais lineares, passando a submarginais orbiculares ou coalescentes tornando os ápices dos lobos involutos, às vezes sendo originados de pústulas. A superfície do talo é grosseiramente maculada e escrobiculada, bastante rachada. A coloração do lado de baixo varia do negro ao marrom escuro, com margens marrons que ficam brancas ou creme nos lobos sorediados. As rizinas são monomórficas, mas do tipo retorcido (Fleig 1997).

\section{Parmotrema asperum Benatti, Marcelli \& Elix, Myco-} taxon 103: 44. 2008.

Fig. 2a-b

Talo sublobado, acinzentado, fragmentário, até $11,0 \mathrm{~cm}$ diâm., coriáceo, saxícola. Lobos de ramificação irregular, (1,0-) 2,0-6,5 mm larg., imbricados nas partes jovens tornando-se amontoados no centro, de adnatos a pouco elevados, pouco adpressos, os ápices de subarredondados a subtruncados ou irregulares, de quase planos a subcôncavos, as margens de crenadas a irregularmente dissecadas, de pouco a muito ascendentes, subonduladas, sublacinuladas. Superfície contínua a irregularmente quebrada, lisa a parcialmente rugosa. Lacínulas do tipo adventícias, irregularmente dispersas pela margem do talo, freqüentemente misturadas à pequenos lóbulos jovens irregulares, planas, curtas, 0,2-2,2 x $0,2-0,9 \mathrm{~mm}$, simples ou irregulares, truncadas a agudas, lado de baixo concolorido à margem inferior. Máculas distintas, densas, de lineares à reticulares, laminais, às vezes originando quebras. Cílios negros, simples, $0,2-0,8(-1,3)$ $\mathrm{x}$ ca. $0,05 \mathrm{~mm}$, de distribuição irregular nas margens, freqüentes em lobos maduros, porém ausentes em alguns lobos jovens. Sorais capitados ou irregulares, em parte coalescentes, com freqüência aglutinando pela incompleta dissolução das pústulas. Sorédios granulares, grosseiros, aglutinados. Pústulas efêmeras, com freqüência ainda que muitas vezes não completamente decompondo-se em sorédios, subapicais nos ápices de lobos e nas extremidades de lacínulas tornando-as pouco involutas, freqüentes também sobre as dobras da lâmina, capitadas a irregulares. Isídios ausentes. Medula branca, sem pigmentações, às vezes manchada pela oxidação do ácido salazínico. Lado de baixo negro, lustroso, de liso a rugoso, papilado. Margem marrom, lustrosa, atenuada, 1,0-3,0 mm larg., lisa, pouco papilada, de nua a parcialmente rizinada,. Rizinas negras mesmo na margem, de simples a furcadas ou às vezes irregulares, em parte aglutinadas, $0,20-1,70(-2,80) \times 0,05-0,10 \mathrm{~mm}$, de freqüentes a abundantes em algumas partes, homogêneas. Apotécios não encontrados. Picnídios submarginais comuns, às vezes também nas lacínulas, de ostíolo negro. Conídios filiformes curtos, $6,5-11,0 \times 1,0 \mu \mathrm{m}$.

Material estudado: BRASIL. São Paulo: Ubatuba, Ilha Anchieta, costão rochoso do Saco Grande, 23/XI/2003, A.A.Spielmann et al. 561, 587a, 609, 613 (SP); idem, em local sombreado do costão na praia, 23/XI/2003, L.S.Canêz \& A.A.Spielmann $607 a(\mathrm{SP})$.

Distribuição conhecida: América do Sul. Brasil: $S P$ (Benatti 2005; Benatti et al. 2008).

Comentários: Esta espécie saxícola é caracterizada pelo talo sublobado, pela cor cinza leitosa devido às máculas laminais, pelas margens irregulares e sublacinuladas parcialmente ciliadas, e também pelos sorais pustulares aglutinados que surgem principalmente subapicais em lobos e lacínulas. A espécie possui um conjunto de características similares às encontradas no antigo gênero Rimelia, notadamente em relação ao aspecto dos lobos e das máculas no córtex superior.

Parmotrema asperum difere de P. anchietanum quanto ao talo sublobado com lobos em geral mais largos (2,0-6,5 $\mathrm{mm})$, irregularmente incisos e sublacinulados. As lacínulas nos talos de $P$. asperum têm forma e padrão de distribuição irregulares, diferente de $P$. anchietanum. São oriundas da dissecação irregular das margens, que faz com que apareçam adventícias em partes velhas, em parte devido à regeneração destas áreas.

Os talos de $P$. asperum possuem uma coloração cinzenta mais esbranquiçada, "leitosa", devido às máculas reticulares espessas que reduzem as áreas com algas a pequeninas "manchas" esverdeadas que salpicam a superfície. Ainda que 
surjam quebras eventuais na superfície originárias ou não destas máculas, não ocorre o padrão rimoso de rachaduras característico das espécies do antigo gênero Rimelia.

Os sorais de $P$. asperum estão dispostos subapicalmente nos lobos e nas lacínulas estendendo-se até as extremidades, aparecendo às vezes sobre as dobras do talo. Como em $P$. anchietanum, os sorédios originam-se de pústulas. Estas desagregam apenas parcialmente em sorédios normalmente grosseiros, e que se aglutinam sem dispersarem. Os sorais em $P$. anchietanum são mais subgranulares e soltos, devido à dissolução das pústulas, desagregando a ponto de deixar a mostra o córtex inferior. Eles formam-se também a certa distância das extremidades, o que parece ter relativa constância.

Tanto as margens inferiores como as rizinas de $P$. asperum apresentam as mesmas características encontradas nos espécimes de $P$. anchietanum (ver a descrição anterior).

Rimelia reticulata difere por ser corticícola, ter córtex superior maculado reticulado e rimoso rachado das margens até o centro, e margens inferiores sempre rizinadas até quase as bordas com rizinas que variam de simples a esquarrosas. Os sorais não se originam de pústulas, mas submarginais nos lobos ou às vezes lineares interrompidos nos ápices de pequenas lacínulas quase as encobrindo (Benatti 2005).

Parmotrema cristiferum (Taylor) Hale também é corticícola, tem lobos mais largos (a maioria 1,0-2,0 cm) e mais arredondados, e um córtex superior de coloração cinza esverdeada, normalmente emaculado. Os sorais são marginais e lineares com um formato acentuadamente sinuoso e mais contínuo, com sorédios de granulação mais fina. As margens são geralmente eciliadas, apresentando formação de cílios somente nas partes mais velhas do centro ou em alguns outros trechos dos talos (Benatti 2005).

Parmotrema margaritatum (Hue) Hale difere pelo formato e largura dos lobos $(7,0-10,0 \mathrm{~mm})$, próximos aos de P. cristiferum (Hale 1965). Os sorais também diferem por serem capitados nos ápices de pequenas lacínulas marginais semelhantes aos de $P$. clavuliferum (Räsänen) Streimann, muitas vezes recobrindo-as fazendo com que os lobos fiquem revolutos (Hale 1965, Brodo et al. 2001). Os sorédios de $P$. margaritatum são também mais soltos e de granulação mais fina, não aglutinando nos sorais.

Parmotrema stuppeum difere de P. asperum também por ser corticícola, possuir lobos mais largos e mais arredondados $(1,0-1,5 \mathrm{~cm})$ como os de $P$. cristiferum também com sorais lineares marginais, cílios mais longos $(2,0-3,0 \mathrm{~mm})$ que são mais raros em espécimes muito sorediados, além de conídios menores (4,0-6,0 Mm comp.) do que os de $P$. asperum (Hale 1965; Brodo et al. 2001).

Parmotrema. subsumptum (Nylander) Hale têm lobos mais largos e mais arredondados $(0,5-1,5 \mathrm{~cm})$ que os encontrados em P. asperum, com sorais lineares iniciando-se marginais e tornando-se submarginais às vezes sendo originados de pústulas, orbiculares ou coalescentes, deixando os ápices dos lobos involutos.
3. Parmotrema cristiferum (Taylor) Hale, Phytologia 28(4): 335. 1974.

Parmelia cristifera Taylor. London Journal of Botany 6: 165. 1847.

Fig. 3a-b

Talo lobado a sublobado, cinza esverdeado, pardo quando em herbário, até $30,0 \mathrm{~cm}$ diâm., subcoriáceo, corticícola. Lobos de ramificação irregular, (3,0-) 4,0-18,5 mm, de contíguos nas partes jovens a imbricados em direção ao centro do talo, freqüentemente formando dobras pregueadas e subcanaliculadas, de pouco adnatos a elevados, às vezes involutos ou revolutos quando sorediados, pouco adpressos, de ápices arredondados a subarredondados, planos quando mais largos $(>10,0 \mathrm{~mm})$ ou às vezes tornando-se côncavos quando mais estreitos $(<10,0 \mathrm{~mm})$, as margens lisas a crenadas, levemente onduladas tornando-se gradativamente mais sinuosas conforme ficam mais sorediadas, de pouco elevadas a elevadas, sublacinuladas. Superfície contínua a irregularmente quebrada, de lisa a pouco rugosa, as quebras e as rugosidades tornando-se mais acentuadas nas partes velhas. Lacínulas do tipo adventícias, curtas, planas, truncadas, 0,4-1,6 x 0,2-1,2 mm, simples, marginais e aleatórias, às vezes misturadas a lóbulos jovens arredondados, lado de baixo marrom, creme ou branco. Máculas normalmente ausentes, às vezes fracas, lineares, laminais, ladeando quebras. Cílios raros e esparsos, ausentes na maior parte da margem, 0,2-0,6 $\mathrm{x}$ ca. $0,05 \mathrm{~mm}$, simples, espalhados aleatoriamente, porém mais comuns em partes velhas. Sorais lineares marginais de contínuos em lobos muito sinuosos a interrompidos ou subcapitados quando nos ápices das lacínulas adventícias, tornando-se mais coalescentes em direção ao centro do talo, raro capitados em algumas outras partes da lâmina. Sorédios farinhosos nas partes jovens tornando-se mais granulares nas partes mais velhas. Pústulas e isídios ausentes. Medula branca, sem pigmentações, às vezes manchada pela oxidação do ácido salazínico. Lado de baixo negro, lustroso, liso a pouco rugoso, parcialmente papilado. Margem inferior marrom, tornando-se branca, creme ou variegada em lobos sorediados, lustrosa, 2,0-10,0 mm larg., de atenuada quando marrom a nítida quando creme ou branca, de lisa a pouco venada, pouco papilada, nua. Rizinas negras, simples, 0,20-0,60 $(-0,80) \times$ ca. $0,05 \mathrm{~mm}$, normalmente poucas, às vezes mais freqüentes ou raro abundantes em algumas partes, agrupadas. Apotécios não encontrados. Picnídios não encontrados.

Material estudado: BRASIL. São Paulo: Bertioga, Praia de Itaguaré, ao lado da antiga ponte sobre o Rio Itaguaré, manguezal, 25/III/1980, M.P.Marcelli \& J.A.Ambraska 1712, 1713 (SP); idem, Praia de Guaratuba, à beira do Rio Guaratuba, no cruzamento com a antiga rodovia, manguezal na beira do rio, 26/XII/1981, M.P.Marcelli 1715 (SP). Cananéia, Ilha do Cardoso, restinga da Vila Marujá, vegetação de restinga pós-dunas ao sul da ilha, 20/X/1981, M.P.Marcelli 

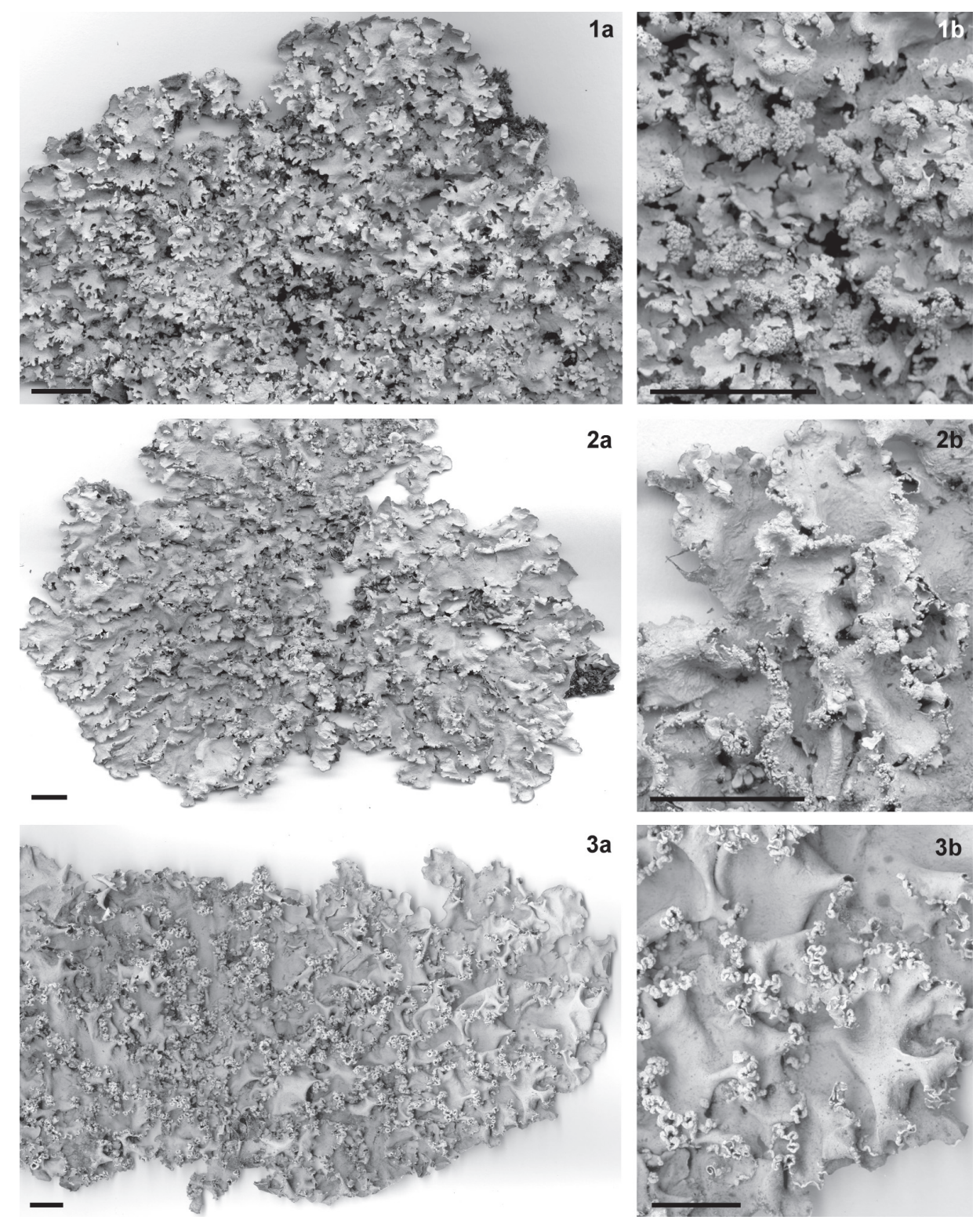

Figura 1. Parmotrema anchietanum Marcelli, Benatti \& Elix. a. Hábito. b. Detalhe (Spielmann 557b, holótipo). Figura 2. Parmotrema asperum Benatti, Marcelli \& Elix. a. Hábito. b. Detalhe (Spielmann 587, holótipo). Figura 3. Parmotema cristiferum (Taylor) Hale. a. Hábito. b. Detalhe (Marcelli 7157). Escalas nas figuras $=1 \mathrm{~cm}$.

1750, 1835 (SP); idem, Praia do Pereirinha, margens do Rio Perequê, manguezal perto da base, 21/X/1981, M.P.Marcelli 1567 (SP). Iguape, Barra do Ribeira, entre o "Rio" Suamirim e o oceano, mata de restinga baixa em solo alagado, 22/VII/1989, M.P.Marcelli \& O.Yano 6933 (SP); idem, árvores em quintal de casa ca. $50 \mathrm{~m}$ do rio, 18/VII/1989, M.P.Marcelli \& O.Yano 7157 (SP). Ilha Comprida, Gambôa Nóbrega, no lado da ilha voltado para o continente, manguezal na margem direita da gambôa na foz, 16/II/1982, M.P.Marcelli 1714 (SP); idem, a ca. de $4 \mathrm{Km}$ da foz, na margem direita, 17/II/1982, M.P.Marcelli 1716 (SP). Itanhaém, Rodovia Padre Manoel da Nóbrega (SP-55) Km 108, no cruzamento com o Rio Itanhaém, manguezal ao lado da rodovia na margem direita do rio, 27/I/1988, M.P.Marcelli \& M.L.M.Santos 17459 (SP); idem, 1/IV/1988, M.P.Marcelli \&
L.R.Fontes 2392, 2394, 2395, 2396 (SP); idem, 15/X/2003, A.A.Spielmann et al. 535 (SP); idem, 15/X/2003, L.S.Canêz et al. 533, 535, 536 (SP); idem, 15/X/2003, P.Jungbluth et al. 615 (SP); idem, Estância Santa Cruz, quase na divisa com Peruíbe, ca. $300 \mathrm{~m}$ do oceano, mata de restinga baixa, 10/ II/2004, M.P. Marcelli et al. 36199, 36224 (SP). Mongaguá, próximo à estação de tratamento de água da SABESP no caminho para o Rio Bichoró, mata de restinga baixa às margens do rio, 15/XII/2003, M.N.Benatti \& M.P.Marcelli 1652 (SP); idem, mata de restinga baixa ao lado da estrada para o rio, 16/ XII/2004, M.N.Benatti et al. 1655, 1667, 1678 (SP). Peruíbe, margem esquerda do Rio Guaraú, manguezal à beira do rio, 24/VII/1988, M.P.Marcelli \& O.Yano 3888, 3953 (SP); idem, nas proximidades da foz, na Base da Faculdade de Ciência e Tecnologia Santa Cecília, 24/VII/1988, M.P.Marcelli 3971. 
Ubatuba, Ilha Anchieta, Praia das Palmas, mata de restinga, próximo à praia, 22/XI/2003, A.A.Spielmann et al. 559 (SP); idem, em pequeno agrupamento de árvores, 22/XI/2003, A.A.Spielmann, L.S.Canêz \& D.F.Peralta 592 (SP); idem, na beira da praia, 22/XI/2003, L.S.Canêz \& A.A.Spielmann 588, 599 (SP); idem, em local aberto, 22/XI/2003, L.S.Canêz \& A.A.Spielmann 592 (SP).

Distribuição conhecida: Oceania, África, Arquipélagos do Índico, Ásia, Arquipélagos do Pacífico, América do Norte, América Central, Caribe e América do Sul. Brasil: SP (Hale 1965).

Comentários: Parmotrema cristiferum é uma das espécies mais facilmente encontradas na região de estudo, facilmente reconhecida em campo pelos lobos geralmente largos (comumente $>1 \mathrm{~cm}$ ), pela escassez de cílios marginais (notáveis nas partes velhas do talo) e pela disposição dos sorais lineares marginais sinuosos. Talos semelhantes, com lobos em geral de $1,0 \mathrm{~cm}$ ou menos de largura, totalmente eciliados e com sorais mais aglutinados podem tratar-se na verdade de $P$. rubifaciens (ver adiante).

Hale (1965) afirmou que $P$. cristiferum é uma das espécies pantropicais mais comuns de Parmeliaceae, e também que se trata de uma das mais facilmente coletadas por botânicos em geral nas áreas tropicais. O autor citou que apotécios são raramente encontrados (nenhum espécime encontrado estava fértil), contendo ascósporos grandes para o padrão do gênero $(26,0-35,0 \times 13,0-18,0 \mu \mathrm{m})$.

Nos talos de $P$. cristiferum é bastante característico os lobos mais largos serem mais planos e de margens ligeiramente onduladas, de lisas a sutilmente crenadas. As margens ficam gradativamente mais sinuosas e abrem conforme ficam sorediadas, o que nas dobras da lâmina faz com que fiquem cada vez mais pregueada e subcanaliculada em direção ao centro. Os sorédios são farinhosos nas partes mais jovens, onde os sorais são mais lineares, finos e mais contínuos, tornando-se eventualmente granulares nas partes mais velhas do centro onde ficam mais espessos e interrompidos. É nas partes velhas do talo que surgem ocasionalmente com mais freqüência cílios simples e esparsos.

As espécies mais semelhantes à $P$. cristiferum são $P$. stuppeum e P. margaritatum. Segundo Hale (1965), a primeira difere pelos cílios longos $(2,0-3,0 \mathrm{~mm})$ que aparecem também nas margens dos lobos mais jovens, pelos sorais marginais que, além de sinuosos, são sempre muito estreitos, e pelos apotécios no geral perfurados e com ascósporos bem menores que os de $P$. cristiferum (12,0-17,0 6,0-9,0 $\mu \mathrm{m})$.

A segunda, $P$. margaritatum, também possui cílios esparsos marginais, porém sendo mais longos que os de P. cristiferum (1,0-1,5 mm). Nesta espécie os sorais são dispostos nos ápices de curtas lacínulas nas margens, em grupos orbiculares que eventualmente coalescem, tornam-se irregulares e estendem-se sobre as lacínulas fazendo com que estas se tornem revolutas (Hale 1965; Brodo et al. 2001).
Parmotrema rubifaciens é extremamente parecida com P. cristiferum, tendo como diferenças: a largura dos lobos, que tendem a ser pequenos, o talo um pouco menos rijo, os sorais mais aglomerados (principalmente no centro) e menos sinuosos, a presença de um pigmento $\mathrm{K}+$ vermelho escuro, total ausência de cílios nas margens e a química medular contendo os ácidos do grupo norstíctico, que reage ao teste $\mathrm{K}$ com uma cor vermelha mais "viva" e próxima de um alaranjado forte.

Parmotrema dilatatum tem sorais marginais mais irregulares e aglomerados freqüentemente em pequenas lacínulas, e química medular diferente caracterizada pela presença dos ácidos úsnico e isoúsnico no córtex superior misturados à atranorina, e dos ácidos protocetrárico e equinocárpico $(\mathrm{K}+$ amarelo, $\mathrm{KC}+$ róseo, $\mathrm{P}+$ alaranjado) na medula, ao invés do ácido salazínico. Parmotrema dilatatum pode ou não apresentar cílios esparsos pela margem (Hale 1965; Fleig 1997), porém poucos espécimes com cílios foram encontrados na localidade de estudo (Benatti 2005).

Parmotrema gardneri é semelhante na morfologia, mas tem lobos menores, sorais menos lineares e mais aglomerados (mais parecidos com os de P. dilatatum), total ausência de cílios nas margens (como em $P$. praesorediosum) e possui como constituinte químico medular o ácido protocetrárico ( $\mathrm{K}+$ róseo, $\mathrm{P}+$ alaranjado). Embora $P$. gardneri tivesse sido colocada como sinônimo de $P$. cristiferum por Hale (1965), ela apresenta de fato diferenças óbvias de morfologia e química medular. Parmotrema dominicanum é semelhante da mesma forma, mas segundo Brodo et al. (2001) os sorais nesta espécie são amarelos devido à presença de ácido úsnico, e a medula também apresenta o ácido protocetrárico.

Parmotrema milanezii Marcelli, Benatti \& Elix tem talo mais membranáceo, mais plano, com cílios bem ramificados nas margens e com freqüência nos sorais. Estes são interrompidos a irregulares (mais parecidos, porém ainda mais curtos que os de $P$. dilatatum) sempre com nítidas margens brancas, lado de baixo mais rizinado, e contendo os ácidos equinocárpico e protocetrárico além de outras substâncias relacionadas ( $\mathrm{K}+$ amarelo, $\mathrm{KC}+$ róseo, $\mathrm{P}+$ alaranjado, $\mathrm{UV}-$ ).

Parmotrema praesorediosum difere pelos lobos mais estreitos, sorais interrompidos com formato de crescente, completa ausência de cílios nas margens, córtex inferior mais rizinado e medula somente com ácidos graxos (todos os testes de coloração negativos). Os conídios de P. praesorediosum são do tipo sublageniformes a lecitiformes, enquanto os de $P$. cristiferum são curto-filiformes.

Parmotrema perlatum possui ácido stíctico medular $(\mathrm{K}+$ amarelo, P+ alaranjado, UV-), e segundo Brodo et al. (2001) também pode ter traços de ácido norstíctico. A disposição dos sorais nas margens é bem característica desta espécie, com sorais capitados a curto lineares dispostos de maneira seqüencial nos ápices de lobos e de lacínulas, que acabam por ficarem involutos. Parmotrema perlatum também tem cílios freqüentes por toda a margem, e que atingem até mais de $2,0 \mathrm{~mm}$ comp. 


\section{Parmotrema expansum Hale, Mycotaxon 5: 435. 1977.} Fig. 4a-b

Talo sublobado, cinza esverdeado, pardo em herbário, até 9,5 cm diâm., subcoriáceo, saxícola. Lobos de ramificação irregular, (2,0-) 4,0-10,0 mm, sobrepostos lateralmente algumas vezes amontoados no centro, pouco elevados, pouco adpressos, os ápices subarredondados a irregulares, às vezes revolutos, outras vezes um pouco côncavos, as margens crenadas ou incisas, dissecadas, às vezes irregularmente lobuladas e sublacinuladas. Superfície quase toda irregularmente quebrada, tornando-se quase rimosa em algumas partes velhas, de lisa a pouco rugosa. Lacínulas do tipo adventícias escassas, curtas, planas, truncadas ou às vezes agudas, 0,4-2,1 x 0,3-1,3 mm, simples a irregulares, mais aparentes em partes velhas do talo, misturadas a pequenos lóbulos jovens irregulares, lado de baixo concolorido à margem inferior. Máculas fracas a distintas, de lineares a reticulares, laminais, principalmente distais nos lobos, às vezes originando quebras. Cílios negros, de simples a furcados ou irregulares, os maiores às vezes dicotômicos ou trifurcados, 0,20-2,10 x 0,05-0,10 mm, abundantes por toda a margem. Sorais, Pústulas e Isídios ausentes. Medula branca, sem pigmentações. Lado de baixo negro, lustroso, de liso a pouco rugoso, parcialmente papilado. Margem inferior marrom, lustrosa, 1,0-3,5 mm larg., atenuada, de lisa a pouco rugosa, nua porém papilada na área de transição para o centro. Rizinas negras, de simples a furcadas ou irregulares, $0,2-1,8 \times$ ca. $0,05(-0,10) \mathrm{mm}$, freqüentes e homogêneas, porém mais abundantes e densamente agrupadas em algumas partes. Apotécios não encontrados. Picnídios comuns, submarginais, de ostíolos negros. Conídios filiformes curtos, $6,0-9,0 \times$ ca. $0,7 \mu \mathrm{m}$.

Material estudado: BRASIL. São Paulo: São Sebastião, Centro de Biologia Marinha (CEBIMAR) da USP, Ponta do Baleeiro, lado S do costão rochoso, 19/III/1988, M.P.Marcelli 2243 (SP).

Distribuição conhecida: América Central e América do Sul. Brasil: MG (Hale 1977) e SP (Benatti 2005).

Comentários: Parmotrema expansum é caracterizada pela ausência de propágulos vegetativos, superfície maculada reticulada com quebras lineares, porém raramente rimosa, e pelos cílios marginais abundantes de simples a comumente bifurcados (alguns até trifurcados ou dicotômicos).

$\mathrm{O}$ aspecto geral dos talos de Parmotrema expansum é bastante semelhante ao de espécies do antigo gênero Rimelia, e particularmente à Parmotrema cetratum (Acharius) Hale. Contudo, em $P$. expansum podem ser notadas máculas inicialmente lineares que desenvolvem para reticulares, em geral mais acentuadas nas áreas mais jovens do córtex superior. Trata-se de um talo não rimoso, a não ser por pequenos trechos em partes velhas onde o aumento do número de quebras acaba por acompanhar o padrão das máculas.
Parmotrema expansum possui a típica margem inferior nua de espécies de Parmotrema, e não apresenta rizinas do tipo esquarrosas.

Segundo Hale (1977), embora haja similaridades dos talos de $P$. expansum com os de $P$. cetratum, os da primeira jamais se tornam sublaciniados no formato como ocorre com a segunda. $\mathrm{O}$ autor atenta também para a ausência do padrão das rachaduras que acompanham as máculas reticulares e cita que os apotécios não são perfurados, como ocorrem em $P$. cetratum (nesta espécie os apotécios podem variar de perfurados a imperfurados num mesmo talo). Parmotrema. cetratum apresenta rizinas esquarrosas misturadas a rizinas simples, e não tem margem inferior nua, como típico para $\mathrm{o}$ antigo gênero Rimelia.

A descrição original, única encontrada na literatura, cita que o talo de $P$. expansum é subfrágil, o que deve significar um talo quebradiço, sendo que isto não é esclarecido nos comentários (Hale 1977). Nesta mesma descrição P. expansum é mencionada com cílios simples a furcados (tais como os observados aqui), sendo que nosso espécime apresenta igual proporção destes cílios, bem como cílios trifurcados ou até dicotômicos em menor freqüência.

Não foram encontrados apotécios, mas segundo Hale (1977) em P. expansum eles costumam ser numerosos, de adnatos a subpedicelados, imperfurados, com ascósporos medindo 16,0-18,0 x 9,0 $\mu \mathrm{m}$. Os conídios em nosso material são de tamanho semelhante aos encontrados por Hale, $(6,0-7,0 \times 0,7 \mu \mathrm{m})$.

Parmotrema ruptum (Lynge) Hale difere por ser corticícola e ter um córtex superior fortemente rimoso-rachado e reticulado-maculado, o que a aproxima ainda mais do aspecto de Parmotrema cetratum. A descrição original de Lynge (1914) de Parmelia rupta (Parmotrema ruptum), menciona um único espécime corticícola, de lobos estreitos (4,0-6,0 mm), cílios menores $(0,5-1,0 \mathrm{~mm})$ e menos ramificados que os encontrados em $P$. expansum. Lynge (1914) citou apotécios dispersos imperfurados contendo ascósporos pequenos e subglobosos $(9,0-11,0 \times 5,5-8,0 \mu \mathrm{m})$, e apenas mencionou os picnídios.

Parmotrema eurysacum (Hue) Hale difere por ser conspicuamente lacinulada, com lacínulas denteadas $(5,0-10,0 \mathrm{x}$ $1,0-2,0 \mathrm{~mm})$, lobos em média mais largos $(8,0-14,0 \mathrm{~mm})$, e cílios menos ramificados e mais longos (1,0-4,0 mm) (Hale 1965). Os apotécios são perfurados, e os ascósporos são pequenos e subglobosos como os de P. ruptum (9,0-12,0 x 6,0-8,0 $\mu \mathrm{m})$. Swinscow \& Krog (1988) comentam que espécimes africanos de $P$. eurysacum têm talos membranáceos e emaculados, e embora não tendo encontrado ascósporos e conídios, citam um espécime mexicano com ascósporos 12,0-16,0 x 8,0-10,0 $\mu \mathrm{m}$ e conídios 8,0-10,0 $\mu \mathrm{m}$. Kurokawa (2001) cita cílios ainda mais longos (até $5,0 \mathrm{~mm}$ ) que os citados por Hale (1965), e ascósporos similares aos citados por Swinscow \& Krog, (14,0-16,0 x 7,0-9,0 $\mu \mathrm{m})$, mencionando que a distribuição dos cílios varia de esparsa a densa. 
Parmotrema mantiqueirense Hale possui talo mais membranáceo que o de $P$. expansum, com lobos mais largos e arredondados $(10,0-20,0 \mathrm{~mm})$, cílios marginais simples e suberetos, e lado de baixo densamente rizinado (Hale 1990). Ainda segundo Hale, os conídios de P. mantiqueirense são maiores que os encontrados aqui em $P$. expansum $(9,0-12,0 \mu \mathrm{m})$

Segundo Hale (1971) e Kurokawa (2001), P. permaculatum (Hale) Kurokawa tem talo similar no formato, incluindo a largura, recorte e disposição de lobos, porém é corticícola, possui talo mais coriáceo, têm apotécios sésseis perfurados, e não apresenta ácido caperático (detectado na cromatografia) junto aos ácidos salazínico e consalazínico. Os lobos de $P$. permaculatum são ainda um pouco maiores em média $(8,0-15,0 \mathrm{~mm})$, bem como os ascósporos $(13,0-16,0$ x 8,0$10,0 \mu \mathrm{m})$. Não é mencionada a presença de qualquer tipo de lóbulos e/ou lacínulas nas margens do talo.

Parmotrema hypermaculatum Marcelli, Benatti \& Elix pode ser diferenciada pelos lobos sobrepostos lateralmente a muito amontoados, córtex superior com máculas reticulares densas e espessas, e cílios bem menos ramificados. Conforme citado, os apotécios de $P$. expansum variam de sésseis a subpedicelados, e têm ascósporos maiores que os de $P$. hypermaculatum (que medem 10,0-14,0 x 6,5-9,0 $\mu \mathrm{m}$ ), que têm também os conídios maiores $(9,0-14,0 \times 1,0 \mu \mathrm{m})$.

Parmotrema despectum Kurokawa é semelhante na morfologia à $P$. expansum, mas segundo Kurokawa (2001) tem talo bastante coriáceo, superfície muito pouco maculada, cílios esparsos a raros, e apotécios perfurados variavelmente rugosos. Esta espécie é mais similar na largura e no recorte dos lobos e também no tamanho dos ascósporos à $P$. hypermaculatum.

Parmotrema reparatum (Stirton) O. Blanco et al. também apresenta máculas efiguradas e rizinas dimórficas típicas do antigo gênero Canomaculina, segundo Kurokawa (2001) menos freqüentes do que em $P$. subcaperatum (Krempelhuber) Hale, mas visíveis em alguns lobos, e um lado de baixo bastante rizinado até às margens. Os apotécios de $P$. reparatum são pedicelados, perfurados e de anfitécio rugoso, com ascósporos maiores $(15,0-18,0 \times 6,0-8,0 \mu \mathrm{m})$ do que os de P. expansum (Kurokawa 2001).

\section{Parmotrema flavescens (Krempelhuber) Hale, Phytologia} 28(4): 336. 1974.

Parmelia glaberrima var. flavescens Krempelhuber. Flora 52: 223. 1869.

Esta espécie foi previamente abordada em Benatti \& Marcelli (2009), junto ao grupo de espécies caracterizado por conter ácidos girofórico ou lecanórico medulares, uma vez que contém ambos os ácidos girofórico e salazínico.

Parmotremaflavescens é caracterizada por ser tipicamente saxícola, talo sublobado, coloração verde amarelada do córtex superior ( $\mathrm{K}-, \mathrm{KC}+$ amarelo, ácido úsnico), margens em geral densamente isidiadas (principalmente nas laterais dos lobos) às vezes com os isídios passando às áreas submarginais ou surgindo por sobre as dobras do talo, e pelos cílios marginais bastante esparsos.

\section{Parmotrema hypermaculatum Marcelli, Benatti \& Elix, Mycotaxon 103: 47. 2008.}

Fig. 5a-b

Talo sublobado, cinza esverdeado, pardo quando em herbário, até 19,0 cm diâm., subcoriáceo, saxícola. Lobos de ramificação irregular, (2,0-) 4,0-11,0 mm larg., sobrepostos lateralmente tornando-se amontoados no centro do talo, adnatos a pouco elevados, pouco adpressos, os ápices subarredondados a irregulares, levemente revolutos, as margens lisas a bastante incisas e crenadas, irregularmente dissecadas e sublacinuladas nas partes mais velhas, ciliadas. Superfície contínua a irregularmente quebrada, quase rimoso-reticulada em alguns trechos, de lisa a escrobiculada. Lacínulas irregulares do tipo adventícias, curtas, espalhadas aleatoriamente nas partes velhas das margens dos lobos, misturadas à pequenos lóbulos jovens irregulares, simples a irregularmente ramificadas, planas, $0,5-2,3 \times 0,4-1,7 \mathrm{~mm}$, truncadas ou raro agudas, lado de baixo concolorido à margem inferior. Máculas lineares a reticulares, distintas e espessas, laminais e nos anfitécios, fracas apenas em apotécios jovens, muitas vezes originando quebras. Cílios negros,em geral simples a raramente furcados ou irregulares, 0,2-2,6 x 0,05-0,15 $\mathrm{mm}$, de poucos a freqüentes na margem. Sorais, Pústulas e Isídios ausentes. Medula branca, sem pigmentações, às vezes manchada pela oxidação do ácido salazínico. Lado de baixo negro, lustroso, de liso a pouco rugoso, às vezes pouco venado e pouco papilado. Margem inferior de marrom a creme ou variegada abaixo dos apotécios, lustrosa, 1,0-5,0 $\mathrm{mm}$ larg., de atenuada quando marrom a nítida quando creme, de lisa a rugosa, nua, parcialmente papilada. Rizinas negras, de simples a furcadas ou irregulares, $0,2-2,2(-3,4)$ x $0,05-0,15 \mathrm{~mm}$, de freqüentes a abundantes, homogêneas. Apotécios submarginais comuns, de côncavos a cupuliformes tornando-se subplanos e fendidos quando velhos, $0,5-$ 7,6 mm, subpedicelados, margem lisa e eciliada, anfitécio liso tornando-se rugoso e rachado quando velho. Disco marrom, não pruinoso, imperfurado, fendido quando velho. Ascósporos elipsóides, 10,0-14,0 x 6,5-9,0 $\mu \mathrm{m}$, epispório ca. 1,0 $\mu \mathrm{m}$ larg. Picnídios submarginais abundantes, nos lóbulos e lacínulas, de ostíolos negros. Conídios filiformes, (7,0-) 9,0-14,0 x 1,0 $\mu \mathrm{m}$.

Material estudado: BRASIL. São Paulo: Itanhaém, Bairro Cibratel, costão rochoso entre a Praia dos Sonhos e a Praia de Itanhaém, 10/I/1989, M.P.Marcelli 4198 (SP); idem, 3/IV/1989, M.P.Marcelli, M.M.Marcelli \& M.M.Marcelli 6224 (SP).

Distribuição conhecida: América do Sul. Brasil: SP (Benatti 2005; Benatti et al. 2008). 
162 Marcelli \& Benatti: Espécies de Parmotrema (Parmeliaceae, Ascomycota) do litoral centro-sul do Estado de São Paulo II...

Comentários: Esta espécie é caracterizada pelo hábito saxícola, córtex superior densamente reticulado maculado (as máculas freqüentemente largas, salpicando o córtex com pequenas "manchas" de áreas com algas), irregularmente quebrado, porém não rimoso (alguns trechos do talo apresentam ocasionalmente mais quebras que os demais, parecendo rimosos), margens ciliadas, ausência de propágulos vegetativos e apotécios curto-pedunculados e lisos (rugosos e fendidos apenas quando velhos) sempre imperfurados e sem ornamentações. A medula apresenta ácido protocetrárico adicionalmente aos do grupo salazínico

Parmotrema hypermaculatum é bastante similar à $P$. permaculatum, diferindo desta espécie que é corticícola, tem talo mais coriáceo, apotécios sésseis perfurados, e não apresenta ácido protocetrárico na medula (Hale 1971, Kurokawa 2001). Segundo estes autores, os lobos de P. permaculatum são um pouco mais largos na média geral $(8,0-15,0 \mathrm{~mm})$, e os ascósporos em média também são maiores (13,0-16,0 x 8,0-10,0 $\mu \mathrm{m})$. Nenhum deles menciona a presença de quaisquer lóbulos e/ou lacínulas surgindo pelas margens dos lobos, que aparentam ser mais lisas e regulares.

Segundo Kurokawa (2001), $P$. despectum difere de $P$. permaculatum pelo talo bastante coriáceo, superfície muito pouco maculada, cílios esparsos a raros, e apotécios perfurados variavelmente rugosos. A medula não apresenta sinais de ácido protocetrárico. A presença de lóbulos arredondados nas margens assemelha as espécies, mas em $P$. hypermaculatum estes (e também as lacínulas) são mais irregulares na forma e distribuição, e também truncados.

Parmotrema cetratum (Acharius) Hale difere por ter um córtex superior reticuladamente maculado e rimoso, desde próximo das margens. Nesta espécie os apotécios variam de perfurados a imperfurados num mesmo talo, e o lado de baixo apresenta rizinas esquarrosas misturadas com rizinas simples - sem apresentar uma margem inferior nua. Outra diferença é a ausência do ácido protocetrárico na medula.

A descrição de Lynge (1914) para Parmotrema ruptum (Lynge) Hale ex DePriest \& B. Hale (=Parmelia rupta Lynge) menciona um único espécime corticícola, de lobos mais estreitos $(4,0-6,0 \mathrm{~mm})$ e cílios menores $(0,5-1,0 \mathrm{~mm})$ do que os de $P$. hypermaculatum. Lynge cita na descrição da espécie que o córtex é reticulado "como em Parmelia cetrata" (Parmotrema cetratum), o que se parece com o material de $P$. hypermaculatum. O autor não citou conídios em seu material embora tenha encontrado muitos picnídios, mas cita apotécios dispersos contendo ascósporos pequenos e subglobosos $(9,0-11,0$ x 5,5-8,0 $\mu \mathrm{m})$. Hale (1960) comentou que o espécime de Lynge era mesmo muito semelhante ao de $P$. cetratum, com um córtex rimoso-reticulado, porém ressaltando a margem nua e citando que o material tratavase de um espécime depauperado. Canêz (2005) mencionou lobos estreitos (1,5-5,0 mm), amontoados, não lacinulados, com cílios curtos (até 1,0 mm), conídios filiformes 10,0-12,5 $1,0 \mu \mathrm{m}$, sem outros ácidos adicionais na medula. Parmelia rupta havia sido considerada como sinônimo de P. eurysa- cum por Fleig (1997), mas trata-se provavelmente (Canêz 2005) de uma espécie diferente. O material tipo (S!) tem cílios ainda menores que os descritos, não ultrapassando 0,5 mm comp. (Benatti et al. 2008).

Conforme é explicado por Spielmann (2005) há uma grande confusão na literatura causada pela incompreensão da real identidade de $P$. ruptum comparada a outras espécies do grupo químico salazínico.

Conforme a descrição de Hale (1977) e nosso material, Parmotrema expansum é também parecida com P. hypermaculatum, sendo diferenciada pelo talo subfrágil (um pouco quebradiço?), lobos pouco imbricados a pouco amontoados, cílios mais freqüentemente ramificados, e pelo córtex superior que fica reticulado e rimoso apenas com a idade devido às quebras na superfície que vão se conectando. Os apotécios encontrados por Hale variam de sésseis a subpedicelados, com ascósporos maiores que os de $P$. hypermaculatum $(16,0-18,0 \times 9,0 \mu \mathrm{m})$, enquanto que os conídios são bacilariformes $(6,0-7,0 \times 0,5 \mu \mathrm{m})$.

Parmotrema eurysacum (Hue) Hale (Hale 1965) difere por ser conspicuamente lacinulada em direção ao centro do talo com lacínulas denteadas $(5,0-10,0 \times 1,0-2,0 \mathrm{~mm})$, com lobos mais largos em média $(8,0-14,0 \mathrm{~mm})$, e cílios mais longos $(1,0-4,0 \mathrm{~mm})$. Hale citou apotécios perfurados contendo ascósporos pequenos e subglobosos como os de P. ruptum $(9,0-12,0 \times 6,0-8,0 \mu \mathrm{m})$.

Swinscow \& Krog (1988) comentaram o padrão de surgimento e do formato das lacínulas vistos em $P$. euysacum, mencionando que nos espécimes africanos os talos também são membranáceos e emaculados. Apesar de não terem encontrado ascósporos e conídios, estes autores citam um espécime mexicano com ascósporos 12,0-16,0 $\mu \mathrm{m} \mathrm{x}$ $8,0-10,0 \mu \mathrm{m}$ e conídios $8,0-10,0 \mu \mathrm{m}$.

Kurokawa (2001) ressaltou as mesmas características apontadas por Swinscow \& Krog (1988), incluindo o padrão das lacínulas e o talo membranáceo emaculado, com cílios ainda mais longos (até 5,0 mm) que os citados por Hale (1965) e ascósporos de tamanho similar aos mencionados por Swinscow \& Krog, $(14,0-16,0$ x 7,0-9,0 $\mu \mathrm{m})$. Kurokawa mencionou ainda que a distribuição dos cílios variava de esparsa a densa e que estes freqüentemente eram ramificados. A medula não contém outras substâncias.

Parmotrema mantiqueirense Hale tem um talo membranáceo de superfície contínua e emaculada, lobos mais largos e arredondados (12,0-20,0 mm) moderadamente ciliados com cílios suberetos, e lado de baixo densamente rizinado em direção ao centro (Hale 1990). Apotécios ainda são desconhecidos para esta espécie, e os conídios tem tamanho aproximado aos de $P$. hypermaculatum $(9,0-12,0 \times 0,5 \mu \mathrm{m})$.

Parmotrema reparatum (Stirton) O. Blanco et al. pode ser diferenciada por apresentar máculas efiguradas e rizinas dimórficas, além de ser rizinada até as bordas das margens. $P$. reparatum também forma apotécios pedicelados e perfurados, de anfitécio rugoso e com ascósporos maiores (15,0-18,0 x $6,0-8,0 \mu \mathrm{m}$ ) que os encontrados em $P$. hypermaculatum. 
7. Parmotrema rubifaciens (Hale) Hale, Phytologia 28: 339. 1974.

Parmelia rubifaciens Hale. Contributions from the United States National Herbarium 36: 261. 1965.

Fig. 6a-b

Talo sublobado, cinza esverdeado, pardo quando em herbário, até $14,0 \mathrm{~cm}$ diâm., subcoriáceo, corticícola. Lobos de ramificação irregular, (3,0-) 4,0-11,0 mm, de contíguos a sobrepostos lateralmente, freqüentemente pregueados e subcanaliculados, de pouco adnatos a elevados, de involutos a revolutos quando sorediados, pouco adpressos, os ápices subarredondados, de subplanos a côncavos, as margens de subcrenadas a crenadas, levemente onduladas tornando-se gradativamente mais sinuosas conforme ficam sorediadas, pouco sublacinuladas. Superfície contínua a irregularmente quebrada, de lisa a pouco rugosa, as quebras e as rugas tornando-se comumente mais acentuadas nas partes velhas. Lacínulas do tipo adventícias, escassas, curtas, planas, truncadas, $0,3-2,0 \quad 0,2-1,5 \mathrm{~mm}$, simples, espalhadas pela margem, lado de baixo concolorido à margem inferior, ou branco. Máculas ausentes ou às vezes fracas, lineares, laminais, ladeando as quebras. Cílios ausentes. Sorais marginais, lineares e contínuos em lobos muito sinuosos, às vezes interrompidos quando nos ápices de pequenas lacínulas, tornando-se progressivamente coalescentes e aglutinados, alguns poucos surgindo como laminais capitados. Sorédios farinhosos nas partes jovens, tornando-se subgranulares ou até granulares nas partes mais velhas. Pústulas e Isídios ausentes. Medula branca, com manchas de um pigmento alaranjado a avermelhado na parte inferior, e que também extravasa pelos sorais. Lado de baixo negro, lustroso, de liso a rugoso, parcialmente pouco venado ou papilado. Margem inferior marrom, tornando-se branca ou variegada em lobos sorediados, atenuada quando marrom a nítida quando branca, lustrosa, 1,5-6,0 mm larg., lisa, em parte pouco venada,e pouco papilada, nua. Rizinas negras, simples, $0,2-0,8(-1,1)$ $\mathrm{x}$ ca. $0,05 \mathrm{~mm}$, poucas às vezes tornando-se mais freqüentes em alguns pontos, comumente aglutinadas, agrupadas. Apotécios não encontrados. Picnídios não encontrados.

Material estudado: BRASIL. São Paulo: Mongaguá, próximo à estação de tratamento de água da SABESP no caminho para o Rio Bichoró, mata de restinga baixa às margens do rio, 15-XII-2003, M.N.Benatti \& M.P.Marcelli $1654 A$ (SP).

Distribuição conhecida: América do Norte; América Central e América do Sul. Brasil: MG (Hale 1965) e SP (Benatti 2005).

Comentários: Parmotrema rubifaciens é um líquen eciliado de margens sorediadas, muito semelhante morfologicamente à $P$. cristiferum (Taylor) Hale, porém encontrado com menos freqüência. Talvez isto se deva por ser realmente menos abundante ou por vício de amostragem dos coletores, já que o talo pode ser facilmente confundido com um pequeno espécime de $P$. cristiferum.

Entre as diferenças consistentes observadas, notou-se que o talo de P. rubifaciens é totalmente destituído de cílios mesmo nas partes velhas, diferindo do observado em espécimes de $P$. cristiferum. Os sorais de $P$. rubifaciens tendem a ficar mais coalescentes e aglomerados do que os visualizados na maioria dos talos de $P$. cristiferum, uma característica notada por Brodo et al. (2001), mas que não se mostrou muito útil para distinguir os espécimes estudados, sendo que alguns espécimes de $P$. cristiferum tinham sorais nas partes centrais do talo por vezes bastante coalescentes e irregulares também. Já a largura dos lobos parece ser mais consistente, sendo que é normal nos espécimes de $P$. cristiferum lobos entre $1-2 \mathrm{~cm}$ larg., enquanto que em espécimes de $P$. rubifaciens o normal parece ser entre $0,5-1 \mathrm{~cm}$ larg.

$\mathrm{O}$ espécime estudado possui um pigmento $\mathrm{K}+$, visível na parte inferior ao se raspar o córtex e também nos sorais, não encontrado em nenhum espécime de $P$. cristiferum. Notou-se que este pigmento concentra-se em alguns pontos manchando o talo, de forma semelhante à manchas deixadas pela oxidação do ácido salazínico em outras espécies como P. cristiferum. Entretanto, a coloração é evidentemente diferente, aparecendo em áreas da medula sem sinais de necrose, reagindo prontamente ao teste de $\mathrm{K}$ (manchas de salazínico apenas encharcam com a aplicação do reagente, sem mudança de cor evidente).

O teste químico K revela uma sutil diferença de coloração para com as espécies contendo ácido salazínico medular: em $P$. rubifaciens a mancha torna-se laranja-avermelhada (cor de "sangue arterial"), devido ao ácido norstíctico. São conhecidas poucas espécies de Parmotrema com ácido norstíctico na medula. São conhecidas outras duas espécies, Parmotrema hypotropum e P. perforatum, que não ocorrem na América do Sul, e que diferem muito na morfologia de P. rubifaciens (Hale 1965, Brodo et al. 2001).

Parmotrema milanezii, uma espécie recém descrita (Marcelli et al. 2008), difere pelo talo mais membranáceo e mais plano, com cílios ramificados marginais muito freqüentemente surgindo nos sorais, estes mais interrompidos e irregulares (mais parecidos, porém mais curtos que os de $P$. dilatatum), sempre com curtas margens brancas alterando brusca e nitidamente para a cor do centro, e um lado de baixo mais rizinado. A medula apresenta ainda outros ácidos, dos grupos equinocárpico e protocetrárico $(\mathrm{K}+$ amarelo, $\mathrm{KC}+$ róseo, $\mathrm{P}+$ alaranjado).

Parmotrema perlatum difere pela presença de ácido stíctico medular ( $\mathrm{K}+$ amarelo, $\mathrm{P}+$ alaranjado), e segundo Brodo et al. (2001) pode ter também traços de norstíctico. A disposição dos sorais, no entanto, é diferente, os sorais de capitados a lineares interrompidos dispostos de maneira seqüencial nos ápices de lobos e lacínulas. Há ainda os freqüentes cílios marginais, estes às vezes com mais de 2,0 mm comp. 

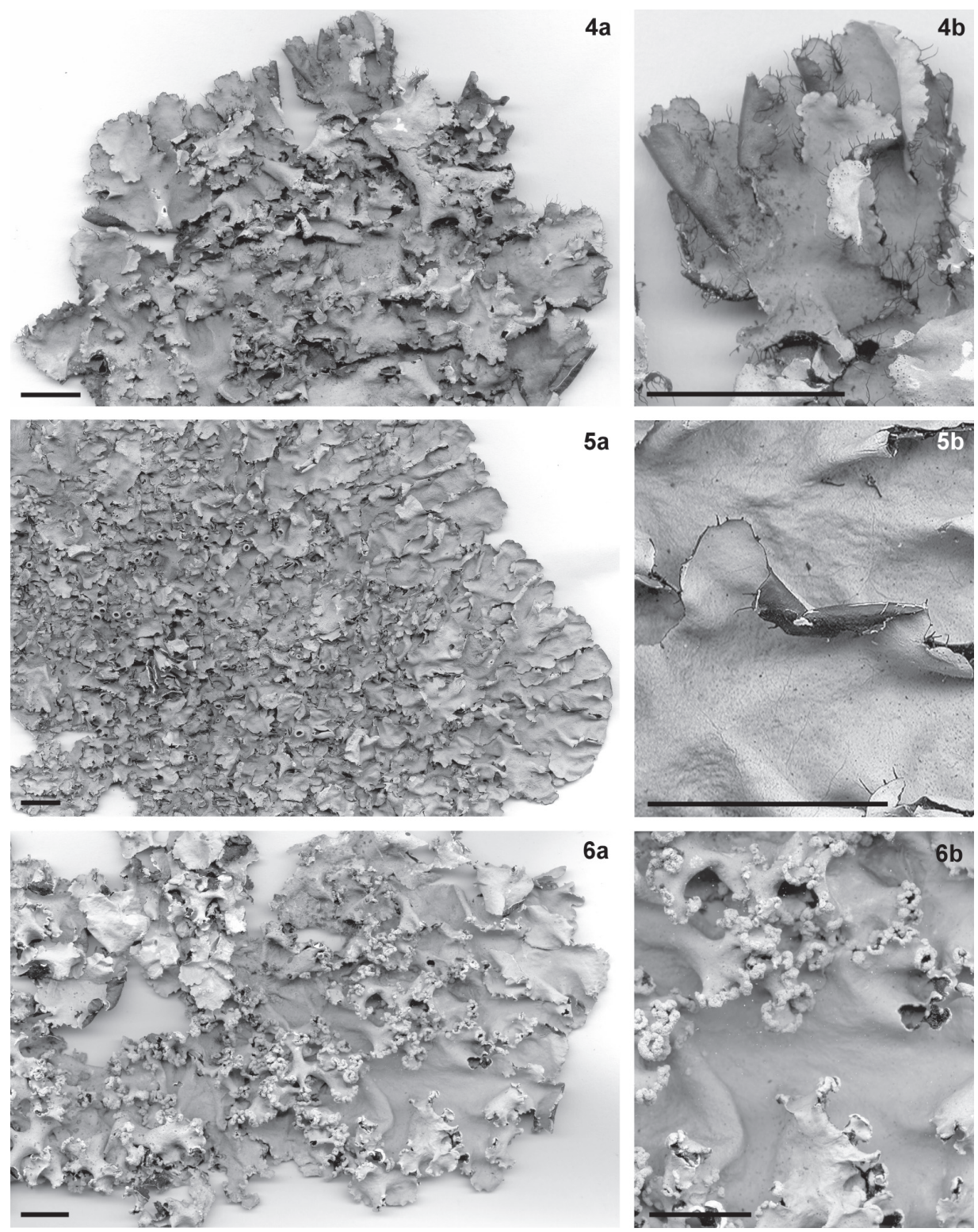

Figura 4. Parmotrema expansum Hale. a. Hábito. b. Detalhe (Marcelli 2243). Figura 5. Parmotrema hypermaculatum Marcelli, Benatti \& Elix. a. Hábito. b. Detalhe (Marcelli 4191, holótipo). Figura 6. Parmotema rubifaciens (Hale) Hale. a. Hábito. b. Detalhe (Benatti 1654a). Escalas nas figuras $=1 \mathrm{~cm}$.

Parmotrema stuppeum e P. margaritatum diferem por possuírem ácido salazínico na medula $(\mathrm{K}+$ amarelo $\rightarrow$ vermelho escuro). Além disto, segundo Hale (1965), ambas são ciliadas, a primeira apresenta sorais marginais sinuosos sempre muito estreitos, e apotécios que são na maioria perfurados. A segunda tem os sorais dispostos nos ápices de lacínulas marginais curtas, orbiculares, que eventualmente coalescem e tornam-se irregulares, estendendo-se sobre as lacínulas e fazendo com que fiquem freqüentemente revolutas (Hale 1965, Brodo et al. 2001).

Parmotrema dilatatum difere por ter sorais menos lineares, mais irregulares e aglomerados, mais freqüentemente em lacínulas curtas, e uma química diferente devido a presença dos ácidos úsnico e isoúsnico no córtex superior misturados à atranorina, e dos ácidos protocetrárico e equinocárpico $(\mathrm{K}+$ amarelo, $\mathrm{KC}+$ róseo, $\mathrm{P}+$ alaranjado) na medula, ao invés do ácido norstíctico. A literatura (Hale 1965, Fleig 1997) cita que espécimes de $P$. dilatatum podem ou não apresentar cílios esparsos ocasionais pela margem.

Ainda sobre outras espécies semelhantes à P. rubifaciens, mas que apresentam ácido protocetrárico $(\mathrm{KC}+$ róseo, $\mathrm{P}+$ alaranjado) como constituinte químico medular, $P$. dominicanum difere também por ter sorais amarelos devido à presença de ácido úsnico (Brodo et al. 2001). Já P. gardneri difere por ter um talo mais coriáceo, lobos menores e sorais menos lineares, mais aglomerados e irregulares (parecidos com os de $P$. dilatatum).

Parmotrema praesorediosum difere pelos lobos mais estreitos, os sorais menos contínuos e em formato de crescente, córtex inferior mais rizinado e medula com todos os testes químicos negativos pela presença somente de ácidos graxos. 
8. Parmotrema spinibarbe (Kurok.) Hale ex DePriest \& B.W.Hale, Mycotaxon 67: 204. 1998.

Parmelia spinibarbis Kurokawa, Bulletin of the Natural Science Museum of Tokyo 17: 299. 1974.

Fig. 7a-b

Talo lobado a sublobado, cinza esverdeado, cinza pardo quando em herbário, até $10,5 \mathrm{~cm}$ diâm., subcoriáceo, saxícola. Lobos de ramificação irregular, 3,5-12,0 mm larg., de contíguos a pouco imbricados, pouco elevados e pouco adpressos, os ápices arredondados a subarredondados, de subcôncavos às vezes côncavos, as margens crenadas, de subplanas a subonduladas, de subascendentes a ascendentes e involutas, de inteiras a parcialmente sublacinuladas. Superfície contínua, com quebras acentuando gradualmente nas partes velhas, de lisa a pouco rugosa. Lacínulas irregulares e adventícias quase inexistentes, apenas poucos lóbulos jovens aparecendo em partes velhas, simples, subarredondados, de subplanos a subcôncavos, $0,4-2,0$ x $0,3-2,0 \mathrm{~mm}$, lado de baixo concolorido à margem inferior. Máculas fracas a distintas, puntiformes, às vezes agregando-se parecendo lineares, laminais. Cílios $0,1-0,8$ $\mathrm{mm}$ comp., de simples a ocasionalmente ramificados na base ou cespitosos, abundantes por toda a margem mesmo nos ápices dos lobos, ainda mais comuns em crenas. Sorais lineares, de submarginais a marginais interrompidos em lobos mais sinuosos, às vezes surgindo subcapitados submarginais em dobras do talo ou nos ápices das poucas lacínulas, aparentando ser originários de pequenas pústulas, em parte tornando-se coalescentes e aglutinados. Sorédios originados de sorais capitados de aspecto pustular, de subgranulares a granulares. Pústulas (?) efêmeras, formadas a partir de pequenas verrucosidades nas áreas marginais e submarginais dos lobos, que logo se dissolvem em sorais. Isídios ausentes. Medula branca, sem pigmentações, às vezes manchada pela oxidação do ácido salazínico. Lado de baixo negro, lustroso, de liso a pouco venado ou pouco rugoso. Margem de marrom escura a avermelhada, lustrosa, 0,5-3,0 mm larg., atenuada, lisa, pouco papilada na área de transição para o centro, nua. Rizinas negras, de simples a irregulares, $0,20-2,30 \mathrm{x}$ ca. $0,05(-0,10) \mathrm{mm}$, abundantes, homogêneas. Apotécios não encontrados. Picnídios submarginais, de ostíolo negro. Conídios não encontrados.

Material estudado: BRASIL. São Paulo: São Sebastião, Centro de Biologia Marinha (CEBIMAR) da USP, Ponta do Baleeiro, no lado S do costão rochoso, 19-III-1988, M.P.Marcelli 2244 (SP).

Distribuição conhecida: América do Sul. Brasil: RJ, SP, PR, RS e SC (Kurokawa 1974; Fleig 1997; Canêz 2005; Spielmann 2005).

Comentários: Parmotrema spinibarbe é caracterizada pelo córtex superior maculado, margens ciliadas, sorais marginais a submarginais coalescentes e aglutinados, e medula contendo a substância liquexantona (UV+ amarelodourado). Parmotrema spinibarbe é muito semelhante à $P$. ultralucens (Krog) Hale, e trata-se provavelmente do par específico sorediado desta espécie. Segundo Eliasaro \& Adler (1997), ambas as espécies têm como espécie parental P. lichexanthonicum Eliasaro \& Adler. Esta similaridade já havia sido constatada por Fleig (1997) ao comparar espécimes de P. ultralucens e P. spinibarbe no estado do Rio Grande do Sul. Fleig citou ainda que Kurokawa (1974) não havia detectado a presença de liquexantona na medula ao ter descrito a espécie (ver outras considerações sob $P$. ultralucens).

As rizinas do único espécime de $P$. spinibarbe encontrado têm espessura um pouco variável, sendo que as de maior espessura e comprimento estão com mais freqüência próximas das margens. Entretanto, não foi notada uma distinção clara de forma entre grupos, como o dimorfismo que é visto em espécies do antigo gênero Canomaculina.

Os sorais aparentam originarem-se de verrucosidades semelhantes a pequenas pústulas, efêmeras e que logo se decompõe nos sorédios. Estas "pequenas pústulas" são mais facilmente percebidas pelo surgimento dos sorais de aspecto subcapitado submarginais, e que quando aglomerados aos das margens, coalescem tornando-as ainda mais involutas. Entretanto, o aspecto pustular é muito breve, e talvez os sorais só aparentem serem originados de pústulas, uma vez que são bem diferentes das pústulas evidentes vistas em espécimes de $P$. anchietanum e $P$. asperum.

Fleig (1997) difere $P$. diffractaicum (Esslinger) Hale (Rimelia diffractaica), que também possui a substância liquexantona na medula, por ter menos cílios, estes raramente ramificados e agrupados na base, uma margem inferior rugosa, e um talo de coloração mais clara, além de não apresentar ácido salazínico, mas sim ácido difractaico na medula (todos os testes de coloração negativos). $\mathrm{O}$ aspecto dos sorais desta espécie, mencionado por Fleig (1997), é também semelhante ao visto em nosso espécime de $P$. spinibarbe.

Parmotrema pontagrossense (Eliasaro \& Adler) O. Blanco et al. (Rimelia pontagrosensis Eliasaro \& Adler) é semelhante na morfologia e na química à $P$. spinibarbe (Eliasaro $\&$ Adler 1998). Não tendo sido encontrada mais nenhuma amostra de $P$. spinibarbe, e por não ter sido possível comparar os tipos de ambas as espécies, não foi possível esclarecer se se tratam de possíveis sinônimos. Conforme citado por Fleig (1997), Kurokawa não evidenciou a presença de liquexantona em Parmelia spinibarbis (Kurokawa 1974). Eliasaro e Adler (1998) também não comparam P. spinibarbe, sendo que as autoras aparentemente desconheciam a presença de liquexantona medular em $P$. pontagrossense à época. Entretanto, segundo Canêz (2005), seu material referido à $P$. pontagrossense apresenta como características divergentes talos com lobos mais contíguos, sorais que se originam a partir de aberturas das margens, sorédios marginais lineares interrompidos mais finos, com sorais mais farinhosos e que 
166 Marcelli \& Benatti: Espécies de Parmotrema (Parmeliaceae, Ascomycota) do litoral centro-sul do Estado de São Paulo II...

são caducos deixando à mostra o córtex inferior devido à fina camada da medula.

\section{Parmotrema ultralucens (Krog) Hale, Mycotaxon 1:} 108. 1974.

Parmelia ultralucens Krog, The Bryologist 77: 253. 1974. Fig. 8a-b

Talo lobado a sublobado, cinza esverdeado, cinza pardo quando em herbário, até 15,0 cm diâm., subcoriáceo, corticícola ou saxícola. Lobos de ramificação irregular, 3,011,5 mm larg., de contíguos a pouco imbricados, em parte amontoados no centro, de adnatos a pouco elevados, pouco adpressos, os ápices arredondados a subarredondados, de subplanos a subcôncavos ou menos freqüentemente côncavos, as margens crenadas, de subplanas a subonduladas, de subascendentes a ascendentes e involutas, inteiras. Superfície contínua, com poucas quebras, de lisa a pouco rugosa. Lacínulas ausentes, às vezes aparecendo lóbulos jovens em partes velhas, simples, subarredondados, subplanos a subcôncavos, $0,4-6,0$ x 0,2-5,0 $\mu \mathrm{m}$, lado de baixo concolorido à margem inferior. Máculas fracas a distintas, puntiformes, às vezes agregando-se parecendo lineares, laminais. Cílios 0,1-1,5 $(-2,0) \mathrm{mm}$ comp., de simples a ocasionalmente ramificados na base, cespitosos ou às vezes até esquarrosos, abundantes por toda a margem mesmo nos ápices dos lobos, ainda mais comuns em crenas. Sorais e Pústulas ausentes. Isídios cilíndricos lisos, $0,05-1,00 \times 0,05-0,10 \mathrm{~mm}$, de simples a pouco ramificados, às vezes bem ramificados ou mais raramente coralóides, eretos, tortuosos, firmes, concoloridos, escurecidos ou de ápices marrons, em parte não ornamentados, outros com ápices ou laterais ciliados, surgindo marginais e nos ápices de dobras, tornando-se laminais nas partes velhas. Medula branca, sem pigmentações, às vezes manchada pela oxidação do ácido salazínico. Lado de baixo negro, lustroso, de liso a pouco rugoso ou pouco venado, as vezes papilado. Margem marrom escura ou avermelhada, lustrosa, 0,5-4,4 mm larg., atenuada, lisa, pouco papilada na transição para o centro, nua. Rizinas negras, de simples a irregulares, 0,20-1,90 $(-2,70)$ x ca. $0,05 \mathrm{~mm}$, abundantes, homogêneas. Apotécios não encontrados. Picnídios não encontrados.

Material estudado: BRASIL. São Paulo: São Sebastião, Centro de Biologia Marinha (CEBIMAR) da USP, Ponta do Baleeiro, no lado S do costão rochoso, 19-III-1988, M.P.Marcelli 2244 (SP).

Bertioga, Praia de Itaguaré, ao lado da antiga ponte sobre o Rio Itaguaré, no manguezal, 25/III/1980, M.P.Marcelli \& J.A.Ambraska 1679 (SP); idem, Praia de Guaratuba, no cruzamento com a antiga rodovia, manguezal à beira do Rio Guaratuba, próximo do rio, 1/VII/1981, M.P.Marcelli 1673, 1676 (SP); idem, no manguezal na margem esquerda do rio, 26/XII/1981, M.P.Marcelli 1675, 1677 (SP). Peruíbe, às margens do Rio Guaraú, nas proximidades da foz, no manguezal na beira do rio, 24/VII/1988, M.P.Marcelli \& O.Yano 3956 (SP); idem, Reserva Ecológica Juréia-Itatins, Núcleo Guarauzinho, no sopé da Serra do Mar, ao redor da sede, 26/VII/1993, M.P.Marcelli \& O.Yano 23697, 23698 (SP); idem, lado esquerdo da desembocadura do Córrego da Água Fria, ao lado da sede, 28/07/1993, M.P.Marcelli \& O.Yano 23767 (SP); idem, costão 29/VII/1993, no lado N da praia, M.P.Marcelli \& O.Yano 23776 (SP).

Distribuição conhecida: (Na descrição original as localidades são apontadas em globo terrestre) África, Ásia, América do Norte e Ilhas do Atlântico Norte, América Central, Caribe e América do Sul. Brasil: SP e RS (Feuerer 2008; Krog 1974; Kurokawa \& Lai 2001; Osorio 1994; Swinscow \& Krog 1988). Krog (1974) explicou que a distribuição na descrição original compreende espécimes diferenciados a partir de material até então misturado, citado na distribuição de Parmelia subcrinita em Hale (1965), e outras localidades adicionais.

Comentários: Parmotrema ultralucens é caracterizada pela formação de isídios comumente ciliados, margens ciliadas com cílios em parte ramificados e pela presença de liquexantona (UV+ amarelo-dourado) na medula. É uma das poucas espécies do grupo que contém ácido salazínico a apresentar liquexantona, as outras sendo $P$. lichexanthonicum Eliasaro \& Adler e P. spinibarbe (Kurokawa) Hale ex DePriest \& B.W.Hale.

Talos de P. ultralucens apresentam cílios marginais com padrão bem variado de ramificação, de simples a cespitosos ou irregulares. As ramificações geralmente ocorrem nas bases dos cílios ou ao menos antes da metade de sua extensão total, sendo comum notar margens muito ciliadas que a olho nu aparentam ter cílios simples, mas que quando vistas com auxílios de lentes apresentam na verdade vários cílios ramificados nas bases.

Os isídios podem ser concoloridos, mais escurecidos que o córtex superior ou ainda de ápices marrons, sendo que esta variação pode ser detectada até em um mesmo talo. É comum também que parte deles seja ciliada, o que foi constatado em todos os espécimes estudados. Nenhum espécime com apotécios ou picnídios foi encontrado, mas Krog (1974) mencionou que os apotécios são raros, imperfurados, com esporos 14,0-17,0 x 10,0-12,0 $\mu \mathrm{m}$. Não foram encontradas citações sobre conídios.

Krog (1974) explicou na descrição original de Parmelia ultralucens que Hale (1965) estudou e relacionou espécimes ainda não esclarecidos quanto à presença de liquexantona na medula junto com espécimes de Parmelia subcrinita Nylander. A autora comentou que o neótipo de Parmelia subcrinita selecionado por Hale foi submetido à época a novas análises químicas em cromatografia, e que foi constatada a presença de ácido salazínico e de norlobaridona na medula, e assim sendo Parmelia subcrinita concordava na morfologia e na química com Parmelia subtinctoria Zahlbruckner. 

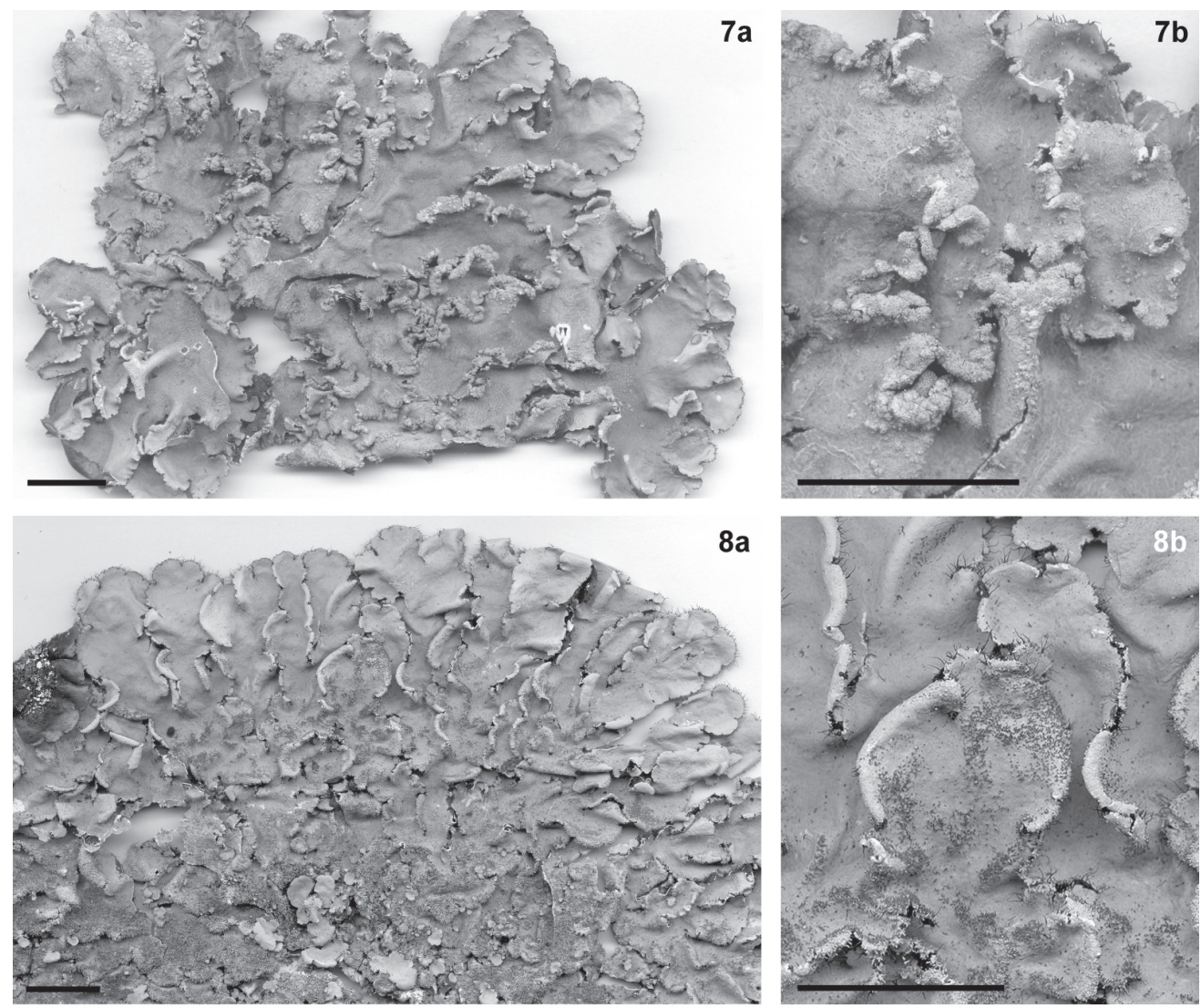

Figura 7. Parmotrema spinibarbe (Kurokawa) Hale. ex DePriest \& B. Hale a. Hábito. b. Detalhe (Marcelli 2244). Figura 8. Parmotrema ultralucens (Krog) Hale. a. Hábito. b. Detalhe (Marcelli 23776). Escalas nas figuras $=1 \mathrm{~cm}$.

Krog (1974) citou também as elucubrações de Asahina (1961), que influenciado pelo ponto de vista de Hale sobre P. subcrinita, esclareceu que os espécimes japoneses anteriormente tidos como desta espécie deveriam na verdade ser referidos como Parmelia subtinctoria. Asahina havia descrito Parmelia subcrinita com os mesmos caracteres morfológicos de $P$ subtinctoria, descrevendo também os cristais de uma substância até então indeterminada, que posteriormente viria a ser descoberta como liquexantona.

Segundo Krog (1974), não se sabia se $P$. subcrinita representava realmente uma espécie distinta como determinado por Nylander, pois houve necessidade de neotipificação de Parmelia subcrinita, descobrindo-se mais tarde que o neótipo tratava-se na realidade de Parmotrema subtinctoria.

$\mathrm{O}$ desconhecimento da existência de liquexantona fez com que durante vários anos espécimes de $P$. ultralucens fossem incorporados em P. subcrinita, sendo que atualmente esta espécie é aceita como um nome rejeitado em prol de $P$. subtinctorum (Zahlbruckner) Hale (= Parmelia subtinctoria) (Hale 1974).

Parmotrema ultralucens é uma das três espécies conhecidas do gênero a apresentar liquexantona medular. Fleig (1997) citou que $P$. spinibarbe é muito semelhante ao material tipo de P. ultralucens. Com base na análise cromatográfica do material estudado e nos apontamentos feitos por
Fleig, é possível afirmar que $P$. spinibarbe trate-se do par sorediado de P. ultralucens. Já P. lichexanthonicum Eliasaro \& Adler trata-se, segundo as considerações das autoras, da espécie parental de $P$. ultralucens e $P$. spinibarbe que não se reproduz por propagação vegetativa (Eliasaro \& Adler 1997).

Segundo Ribeiro (1998) e Marcelli \& Ribeiro (2002), $P$. neosubcrinitum Ribeiro \& Marcelli pode ser diferenciada de P. ultralucens pela ausência de liquexantona na medula e pelos isídios grandes $(3,0-10,0 \mathrm{~mm})$, achatados nos ápices e não sorediados, que se formam a partir da dissecação das margens do talo. Ribeiro (1998) explicou o processo que levou à sinonimização de $P$. subcrinita em $P$. subtinctoria devido à perda do material tipo, e a neotipificação de um espécime por Hale (1965) e que Krog (1974) descobriu tratar-se na verdade de Parmelia subtinctoria, explicando que a nova espécie encontrada encaixava-se melhor do que $P$. ultralucens, separada por Krog de P. subtinctoria por conter liquexantona medular na descrição original de $P$. subcrinita, razão pela qual foi atribuído o nome $P$. neosubcrinitum.

Parmotrema enteroxanthum Hale difere pela ausência de cílios nas margens, isídios inflados, medula amarelada sem a presença de liquexantona. Outra espécie, Parmotrema guyanum Hale, também é eciliada, contém ácido norstíctico medular, mas também sem apresentar liquexantona. 
168 Marcelli \& Benatti: Espécies de Parmotrema (Parmeliaceae, Ascomycota) do litoral centro-sul do Estado de São Paulo II...

\section{Referências bibliográficas}

Andrade, M.A.B. 1967. Contribuição ao conhecimento da ecologia das plantas das dunas do litoral do Estado de São Paulo. Boletim da Faculdade de Filosofia, Ciências e Letras da Universidade de São Paulo - Botânica 22: 3-170.

Andrade, M.A.B. \& Lamberti, A. 1965. A Vegetação. In A. Azevedo (coord.) A Baixada Santista - Aspectos Geográficos (Vol. 1): 151-177. São Paulo, EDUSP.

Asahina, Y. 1961. Lichenologische Notizen (182-184). Journal of Japanese Botany 36(9): 289-291.

Asahina, Y. \& Shibata, S. 1954. Chemistry of Lichen Substances. Japan Society for the Promotion of Science. Tóquio, Ueno.

Benatti, M.N. 2005. Os gêneros Canomaculina, Parmotrema e Rimelia (Parmeliaceae, Ascomycetes) no litoral centro-sul do estado de São Paulo. Dissertação de Mestrado. Instituto de Botânica, São Paulo.

Benatti, M.N. \& Marcelli, M.P. 2007. Gêneros de fungos liquenizados dos manguezais do Sul-Sudeste do Brasil, com enfoque no manguezal do Rio Itanhaém, Estado de São Paulo. Acta Botanica Brasilica 21(4): 863-878.

Benatti, M.N. \& Marcelli, M.P. 2009. Espécies de Parmotrema (Parmeliaceae, Ascomycota) do litoral centro-sul do Estado de São Paulo I. Grupos químicos girofórico e lecanórico. Acta Botanica Brasílica 23: 1013-1026.

Benatti, M.N., Marcelli, M.P. \& Elix, J.A. 2008. Three new species of Parmotrema containing salazinic acid from the coast of São Paulo State, southeastern Brazil. Mycotaxon 103: 41-52.

Brodo, I.M.; Sharnoff, S.D. \& Sharnoff, S. 2001. Lichens of North America. London, Yale University Press.

Bungartz, F. 2001. Analysis of lichen substances. Disponível em http:// ces.asu.edu/ASULichens/plb 400/laboratory/ chemistry/tlc.html. Acessado 15 out. 2004.

Canêz, L.S. 2005. A Família Parmeliaceae na localidade de Fazenda da Estrela, Município de Vacaria, Rio Grande do Sul, Brasil. Dissertação de Mestrado. Instituto de Botânica, São Paulo.

Eiten, G. 1970. A Vegetação do Estado de São Paulo. Boletim do Instituto de Botânica 7: 1-22.

Eliasaro, S. \& Adler, M. 1997. Two new species and new reports in the Parmeliaceae sensu stricto (Lichenized Ascomycotina) from Brazil. Mycotaxon 63: 49-55.

Eliasaro, S. \& Adler, M. 1998. Rimelia pontagrossensis, a new species in the Parmeliaceae sensu stricto (Lichenized Ascomycotina) from Brazil. Mycotaxon 66: 127-130.

Eliasaro, S. \& Donha, C.G. 2003. The genera Canomaculina and Parmotrema (Parmeliaceae, lichenized Ascomycota) in Curitiba, Paraná State, Brazil. Revista Brasileira de Botânica 26(2): 239-247.

Feuerer, T.E. (ed.) 2008. Checklists of lichens and lichenicolous fungi. Versão I Junho de 2006. In http://www.checklists.de.

Fink, B. 1905. How to collect and study lichens. The Bryologist 8 (2): 22-27.

Fleig, M. 1997. Os gêneros Parmotrema, Rimelia e Rimeliella (LichenesAscomycota, Parmeliaceae) no Rio Grande do Sul, Brasil. Tese de Doutorado, Instituto de Biociências da Universidade de São Paulo.

Galloway, D.J. 1985. Flora of New Zealand - lichens. Wellington, Government Printer.

Hale, M.E. 1960. A revision of the South American species of Parmelia determined by Lynge. Contributions from the United States National Herbarium 36(1): 1-41.
Hale, M.E. 1965. A Monograph of the Parmelia subgenus Amphigymnia. Contributions from the United States National Herbarium 36(5): 193-358.

Hale, M.E. 1971. Parmelia permaculata, a new lichen from Alabama and Mexico. Phytologia 21(6): 425.

Hale, ME. 1974. New combinations in the lichen genus Parmotrema Massalongo. Phytologia 28(5): 334-339.

Hale, M.E. 1977. New species in the lichen genus Parmotrema Massalongo. Mycotaxon 5(2): 432-448.

Hale, M.E. 1979. How to know the Lichens. The Pictured-Key Nature Series. Dubuque, Wm. C. Brown Company Publishers.

Hale, M.E. 1990. New species of Parmotrema (Ascomycotina: Parmeliaceae) from Tropical America. Bibliotheca Lichenologica 38: 109-119.

Huneck, S. \& Yoshimura, I. 1996. Identification of Lichen Substances. Berlin, Springer-Verlag.

Krog, H. 1974. Parmelia ultralucens, a new lichen species in subgenus Amphigymnia. The Bryologist 77: 253-256.

Kurokawa, S. 1974. Four new species of Parmelia from Brazil. Bulletin of the Natural Science Museum of Tokyo 17: 297-300.

Kurokawa, S. 2001. Taxonomic notes on Parmelia reparata (Parmeliaceae, Lichenes) and the related species. Bulletin of the Natural Science Museum of Tokyo, ser. B, 27(1): 1-10.

Kurokawa, S. \& Lai, M-jou 2001: Parmelioid lichen genera and species in Taiwan. Mycotaxon 77: 225-284.

Lynge, B. 1914. Die Flechten der ersten Regnellschen Expedition. Die Gattungen Pseudoparmelia gen. nov. und Parmelia Ach. Arkiv för Botanik 13(13): 1-172.

Marcelli M.P. 2004. Checklist of lichens and lichenicolous fungi of Brazil. Version 1: June 2004. http://www.biologie.uni-hamburg.de/ checklists/brazil 1.htm.

Marcelli M.P. \& Ribeiro C.H. 2002. Twenty-one new species of Parmeliaceae from southern Brazil. Mitteilungen aus dem Institut für Allgemeine Botanik in Hamburg 30-32: 125-155.

Nash III, T.H. \& Elix, J.A. 2002. Parmotrema. Pp. 318-329. In: Nash III, T.H., Ryan, B.D., Gries, C. \& Bungartz, F. (eds.). Lichen Flora of the greater Sonoran Desert Region. V. 1. Lichens Unlimited. Tempe, Arizona State University.

Orange, A., James, P.W. \& White, F.J. 2001. Microchemical methods for the identification of lichens. London, The British Lichen Society.

Ribeiro, C.H. 1998. A família Parmeliaceae (Ascomycota liquenizados) em Regiões montanhosas dos estados de Minas Gerais, Rio de Janeiro e São Paulo. Dissertação de Mestrado, Instituto de Biociências da Universidade de São Paulo.

Spielmann, A.A. 2005. A família Parmeliaceae (fungos liquenizados) nos barrancos e peraus da encosta da Serra Geral, no Vale do Rio Pardo, Rio Grande do Sul, Brasil. Dissertação de Mestrado. Instituto de Botânica, São Paulo.

Swinscow, T.D.V. \& Krog, H. 1988. Macrolichens of East Africa. London, British Museum of Natural History.

Walker, J.W. \& James, P.W. 1980. A revised guide to microchemical techniques for the identification of lichen products. Bulletin of the British Lichen Society 46(supl.): 13-29.

White, F.J. \& James, P.W. 1985. A new guide to microchemical techniques for the identification of lichen substances. Bulletin of the British Lichen Society 57(supl.): 1-41. 